\title{
Health Risk Assessment of Heavy Metals and Lipid Quality Indexes in Freshwater Fish from Lakes of Warmia and Mazury Region, Poland
}

\author{
Joanna Łuczyńska *(i) and Beata Paszczyk \\ Faculty of Food Sciences, University of Warmia and Mazury in Olsztyn, ul. Plac Cieszyński 1, 10726 Olsztyn, \\ Poland; paszczyk@uwm.edu.pl \\ * Correspondence: jlucz@uwm.edu.pl; Tel.: +48-89-523-41-65
}

Received: 17 September 2019; Accepted: 4 October 2019; Published: 8 October 2019

\begin{abstract}
The objectives of study were to determine heavy metals content ( $\mathrm{Zn}, \mathrm{Cu}, \mathrm{Mn}, \mathrm{Fe}$ and $\mathrm{Hg}$ ) and fatty acids in selected organs of roach, Rutilus rutilus (L.); bream, Abramis brama (L.); pike, Esox lucius (L.); Eurasian perch, Perca fluviatilis (L.) collected from reservoirs of Warmia and Mazury region (northeastern Poland). Heavy metals were determined with atomic absorption spectrometry AAS. The fatty acids were analyzed using gas chromatography. In a few cases, differences in the content of heavy metals and fatty acids were not significant between species. The muscles of fish characterized significantly higher values of mercury than other organs $(p \leq 0.05)$, except for bream. The reverse regularity was observed in the case of content of $\mathrm{Cu}, \mathrm{Zn}, \mathrm{Mn}$ and Fe. Fatty acids having a desirable dietary effect in humans (DFA-Hypocholesterolaemic fatty acids) (74.00-74.84) were more than OFA (hypercholesterolaemic fatty acids), i.e., those undesirable (24.03-24.79). The lipid quality indexes AI (index of atherogenicity) (0.40-0.44) and TI (index of thrombogenicity) (0.18-0.24) in muscles of fish were low, which means that the meat of the fish may be recommended for human health. THQ (target hazard quotient) and HI (hazard index) as individual foodstuff were below 1, whereas HI for a specific receptor/pathway combination exceeded 1. This may suggest that eating meat from a given species is safe from a health point of view.
\end{abstract}

Keywords: organs of fish; metals; target hazard quotient; dietary intake; lipid quality indexes

\section{Introduction}

A properly balanced diet, including the amount of fish consumed, is a way to maintain the health and balance of the human body, as well as physiological functions [1]. Fish and fish products play a major role from a nutritional point of view because they are a rich source of nutrients, and provide a relatively low caloric content [2]. Moreover, fish flesh has a good digestibility [3]. According to Pal et al. [2], fish also provide a good balance of protein, and their availability and affordability is better than other animal protein sources [4]. It is also known that fish and fish oils (along with some vegetable oils) are a good source for essential polyunsaturated fatty acids in human nutrition [3,5]. Many clinical trials have shown the relationship between the intake of n-3 PUFA (polyunsaturated fatty acids) and beneficial effects in different diseases (optimal cardiovascular system, brain and vision functioning, cancer prevention, arthritis, hypertension and diabetes mellitus) [2,5-8]. Since both linoleic acid (LA) and $\alpha$-linolenic acid (ALA) cannot be synthesized in the body, they are therefore essential [9-11]. LA can be converted via $\gamma$-linolenic acid (18:3n-6) and dihomo- $\gamma$-linolenic acid (20:3n-6; DGLA) to arachidonic acid (20:4n-6; AA). ALA is the precursor for synthesis of eicosapentaenoic acid (20:5n-3; EPA) and further to docosapentaenoic acid (22:5n-3; DPAn-3) and docosahexaenoic acid (22:6n-3; DHA) [12]. However, among fatty acids, there are some saturated fatty acids (SFA) that have different 
effects on the content of plasma lipoprotein cholesterol fractions. These include to lauric (C12:0), myristic (C14:0) and palmitic acids (C16:0), which increase LDL cholesterol, whereas stearic has no effect. Therefore, replacing SFA (C12:0-C16:0) with polyunsaturated fatty acids (PUFA) decreases LDL cholesterol concentration and the ratio of total/HDL cholesterol. A similar, but lesser effect, is achieved by replacing these SFA with monounsaturated fatty acids (MUFA) [13]. It is clear that saturated fatty acids are hypercholesterolemic fatty acids and monounsaturated fatty acids are neutral or mildly hypocholesterolemic, whereas polyunsaturated fatty acids show the most potent hypocholesterolemic effects [14].

The numerous health benefits provided by fish consumption may be compromised by the presence of undesired substances [15]. The fish take up metals not only from the water, but also from the diet. Thus, the rate of metal accumulation by various aquatic biota and the type and length of food chains determine the amount of dietary metal absorbed by fish [16]. In addition, the amount of metals in the fish body is also influenced by such factors as the type of fish, season, reproductive stage and age, which affect the amount of nutrients and contaminants within a single species as well as between species [15]. These heavy metals pose a danger as chemical water pollution due to their bioaccumulation potential and biomagnification, but it is also known that they cannot be eliminated from the body by metabolic activities [17]. The studies conducted by these authors [17] also showed that heavy metals cause severe damage to fish, thus endangering fish health and the ecosystem. They pose a threat to human health as well via the consumption of heavy metal contaminated fish. Therefore, contaminated meat has no economic value because it is too toxic for consumers [1]. These metals belong to the group of "trace elements", and their concentration in the body ranges from $0.00001 \%$ to $0.01 \%$ (e.g., $\mathrm{Fe}, \mathrm{Zn}, \mathrm{Cu}$ and $\mathrm{Mn}$ ) and they are involved in natural quantities in the regulation of vital functions at all stages of development of the living organism. Iron participates in a wide variety of metabolic processes, including oxygen transport, DNA synthesis and electron transport [18]. Zinc is a component of numerous enzymes, hormone life insulin, growth hormone and sex hormone. This metal is the second trace mineral in the body after iron [19]. Manganese acts as a cofactor for a variety of enzymes, including arginase, glutamine synthetase, pyruvate carboxylase and Mn superoxide dismutase. Through these metalloproteins, this element plays critically important roles, among others, in antioxidant defense, development, digestion and reproduction [20]. Copper-like iron and manganese is a cofactor for numerous enzymes. In addition, it plays an important role in central nervous system development and is required for cellular respiration, neurotransmitter biosynthesis, peptide amidation, pigment formation and connective tissue strength [21]. The other group is "ultratrace elements", and their concentration is lower than $0.000001 \%$ (e.g., $\mathrm{Hg}$ ) [22]. Mercury may cause both toxicological cellular and cardiovascular, hematological, pulmonary, renal, immunological, neurological, endocrine, reproductive and embryonic toxicological effects [23].

Therefore, the aim of this study was:

1) The identification of the differences between mercury, zinc, iron, copper and manganese concentration in four freshwater fish species, and their organs (muscles, liver and gills), as well as the impact of biometric parameters (body weight and total length) in fish organs.

2) The identification of the differences between fatty acids and the lipid quality indexes in muscles of examined fish.

3) To examine the health risk assessment using estimated daily intake (EDI), hazardous index (HI), target hazard quotient (THQ) and other indexes.

\section{Materials and Methods}

\subsection{Sampling and Sample Preparation}

Predatory (European perch, Perca fluviatilis L. and pike, Esox lucius L.) and non-predatory fish (roach, Rutilus rutilus L. and bream, Abramis brama L.) were caught from the Olsztyn lake District (October 2013) (Figure 1). The fish were weighed and measured after being brought to the laboratory. 
Muscles (without skin) from the dorsal part, liver and gills were prepared from one specimen and stored until analysis in the refrigerator at $-30^{\circ} \mathrm{C}$. To avoid sample contamination, all organs were collected with a plastic knife and stored in sealed plastic bags.
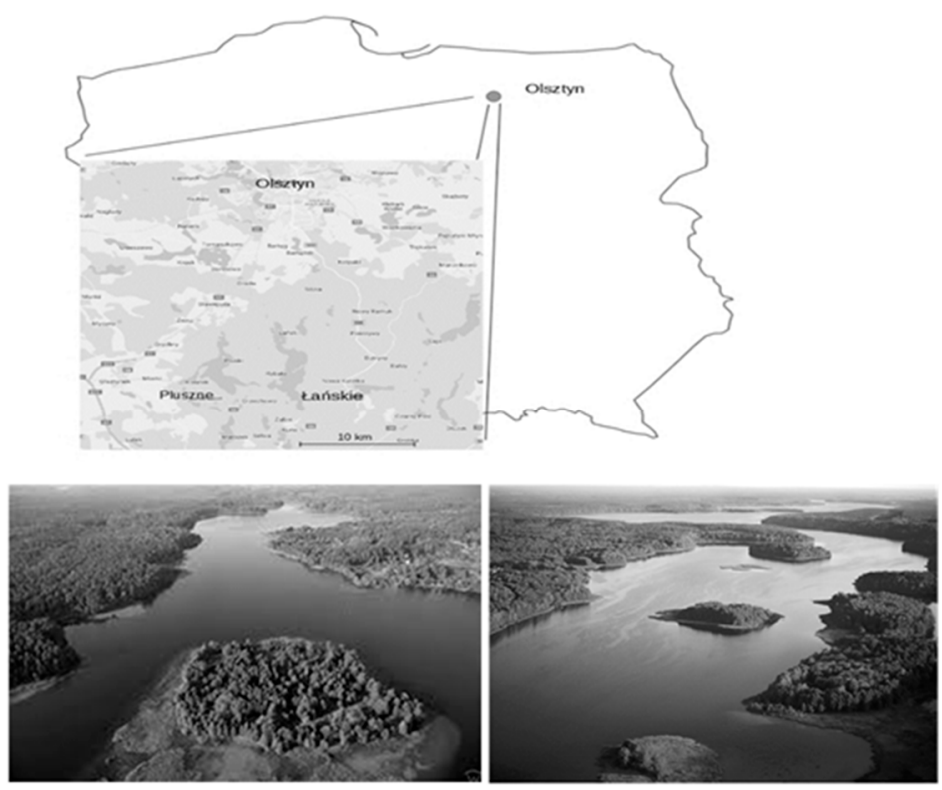

Figure 1. The study area was located in north-eastern Poland, near the city Olsztyn.

Ethical permit: fish were bought at the fish farm and were already dead. According to European and Polish Law, the research done on the tissue of commercially caught fish is free from obtaining permission from the Local Ethical Commission.

\subsection{Element Analysis}

\subsubsection{Mercury}

Duplicate samples of organs were weighed into quartz boats $(<270 \mathrm{mg} \pm 0.0001 \mathrm{~g})$. The total mercury was processed with atomic absorption spectrometry thermal decomposition using Milestone DMA-80 with dual-cell and UV enhanced photodiodes (Italy). Conditions for the determination of mercury is described in an earlier publication [24].

\subsubsection{Zinc, Copper, Iron and Manganese}

For the determination of zinc, copper, iron and manganese in muscles of fish examined, samples were ashed at $450{ }^{\circ} \mathrm{C}$ using laboratory furnaces (Nabertherm, Germany). After obtaining the white ash, it was dissolved in $1 \mathrm{M} \mathrm{HNO}_{3}$ (Suprapur-Merck, Darmstadt, Germany) and transferred with deionized water (Merck-Millipore Elix Advantage 3, USA) into a volumetric flask of volume $25 \mathrm{~mL}$. After weighing, samples of liver and gills were placed in a boro-silica glass tube and mineralized with a nitric and perchloric acid mixture (Merck, Darmstadt, Germany, 3:1, v/v) at $190{ }^{\circ} \mathrm{C}$. For this purpose, a heating block with a programmable temperature and digestion time was used (DK 20, VELP Scientifica, Italy). The resulting solution was transferred to flasks with a volume of $25 \mathrm{~mL}$, using deionized water.

\subsection{Instrumental Analysis and Quality Control}

Samples were prepared in two parallel wells. The total mercury was determined using Milestone DMA-80 with dual-cell and UV enhanced photodiodes (Italy). The detection limit (LOD) was 0.02 $\mu \mathrm{g} / \mathrm{kg}$. The quality control of methods was tested using the reference material: BCR CRM 422 (muscles of cod, Gadus morhua (L.)) with a certified value of mercury. The recovery rate of Hg was $100.2 \%(n=4)$. 
Concentrations of zinc, copper, iron and manganese were measured using the flame atomic absorption spectrometry (iCE 3000 Series AAS, Thermo Scientific, Loughborough, England). Four blanks and four standards were analyzed with each batch of samples. The absorptions wavelength was as follows: $213.9 \mathrm{~nm}$ for zinc and $324.8 \mathrm{~nm}$ for copper. The calibration curves were prepared using four solution standards $(1000 \mu \mathrm{g} / \mathrm{L})$ with $0.1 \mathrm{M} \mathrm{HNO}_{3}$ supplied by J.T.Baker ${ }^{\circledR}$ (Deventer, Netherlands). The calibration curves were linear within the range of metal concentration (regression coefficients $R^{2} \geq$ 0.999). The absorption wavelengths were as follows: $248.3 \mathrm{~nm}$ for iron, $213.9 \mathrm{~nm}$ for zinc, $324.8 \mathrm{~nm}$ for copper, $279.5 \mathrm{~nm}$ for manganese. The detection limits (LOD) were $0.5 \mathrm{mg} / \mathrm{kg}$ for $\mathrm{Fe}, 0.1 \mathrm{mg} / \mathrm{kg}$ for $\mathrm{Zn}$, $0.05 \mathrm{mg} / \mathrm{kg}$ for $\mathrm{Cu}$ and $0.05 \mathrm{mg} / \mathrm{kg}$ for Mn. Sensitivity was as follows: $0.05,0.05,0.02$ and $0.02 \mathrm{mg} / \mathrm{L}$. The quality control of methods was tested using the elements in reference material: BCR CRM 422 (muscles of cod Gadus morhua (L.)) with a certified value of zinc, copper and mercury. The recovery rates were: $105.0 \% \mathrm{Zn}, 103.0 \% \mathrm{Cu} .96 \% \mathrm{Fe}$ and $103 \% \mathrm{Mn}$, respectively.

\subsection{Fatty Acids Analysis}

The lipids were extracted according to the Folch's procedure [25]. The fatty acid methyl esters were prepared from total lipids with the Peisker method with chloroform, methanol and sulphuric acid (100:100:1 v/v) [26].

The fatty acids of methyl esters of each sample were analyzed using 7890A Agilent Technologies chromatograph with a flame-ionization detector (FID) (Agilent Technologies, INC., Santa Clara, California, USA) under the following conditions: capillary column (dimension $30 \mathrm{~m} \times 0.25 \mu \mathrm{m}$ with a $0.32 \mathrm{~mm}$ internal diameter, liquid phase StabilwaxR), temperature: flame-ionization detector $-250{ }^{\circ} \mathrm{C}$, injector $-230{ }^{\circ} \mathrm{C}$, column $-190^{\circ} \mathrm{C}$, carrier gas - helium with a flow rate $1.5 \mathrm{~mL} / \mathrm{min}$. Individual fatty acids were identified by comparing the relative retention time peaks to the known Supelco's standards.

\subsection{The Lipid Quality Indexes (AI and TI)}

They were calculated using the following pattern by Ulbricht and Southgate [27] and Garaffo et al. [28]:

Index of atherogenicity (AI):

$$
\mathrm{AI}=[\mathrm{C} 12: 0+(4 \times \mathrm{C} 14: 0)+\mathrm{C} 16: 0] /(\mathrm{n}-3 \mathrm{PUFA}+\mathrm{n}-6 \mathrm{PUFA}+\mathrm{MUFA})]
$$

Index of thrombogenicity (TI):

$$
\begin{aligned}
& \mathrm{TI}=[\mathrm{C} 14: 0+\mathrm{C} 16: 0+\mathrm{C} 18: 0] /[(0.5 \times \mathrm{C} 18: 1)+(0.5 \times \text { sum of other MUFA })+(0.5 \\
& \times \mathrm{n}-6 \text { PUFA })+(3 \times \mathrm{n}-3 \text { PUFA })+\mathrm{n}-3 \text { PUFA } / \mathrm{n}-6 \text { PUFA })]
\end{aligned}
$$

Flesh-lipid quality (FLQ) were calculated presented by Abrami et al. [29] and Senso et al. [30]:

$$
\mathrm{FLQ}=100 \times(\mathrm{EPA}+\mathrm{DHA}) /(\% \text { of total fatty acids })
$$

Hypercholesterolaemic fatty acids (OFA):

$$
\mathrm{OFA}=\mathrm{C} 12: 0+\mathrm{C} 14: 0+\mathrm{C} 16: 0
$$

Hypocholesterolaemic fatty acids (DFA):

$$
\mathrm{DFA}=\mathrm{C} 18: 0+\mathrm{UFA}
$$




\subsection{Human Health Risk Assessment}

\subsubsection{Estimated Daily Intake of Mercury (EDI)}

EDI is the estimated daily intake ( $\mu \mathrm{g} / \mathrm{kg}$ body weight/day), and is obtained as follows:

$$
\mathrm{EDI}=\mathrm{C} \times \mathrm{IR} / \mathrm{BW}
$$

where $C$ is the average concentration of mercury in food stuffs ( $\mu \mathrm{g} / \mathrm{g}$ wet weight), IR is the daily ingestion rate (g/daily) and $\mathrm{BW}$ is the average body weight $(60 \mathrm{~kg})$ [31].

\subsubsection{Target Hazard Quotient (THQ)}

According to Ahmed et al. [32] and US EPA [33], THQ estimated the non-carcinogenic health risk of consumers due to intake of heavy metal contaminated fish use an oral reference dose of $\mathrm{Hg}$, $\mathrm{Zn}, \mathrm{Cu}, \mathrm{Fe}$ and $\mathrm{Mn}\left(\mathrm{RfD}=3.00 \times 10^{-4}, 3.00 \times 10^{-1}, 7.00 \times 10^{-1}, 1.4 \times 10^{-1}\right)$. When THQ $<1$, there is health benefit from fish consumption and the consumers are safe, whereas THQ $>1$ suggests a high probability of adverse risk of human health.

$$
\mathrm{THQ}=(\mathrm{EFr} \times \mathrm{ED} \times \mathrm{FiR} \times \mathrm{C} / \mathrm{RfD} \times \mathrm{BW} \times \mathrm{TA}) \times 10^{-3}
$$

where Efr is the exposure frequency (365 days/year), ED is the exposure duration (70 years), FiR is the fish ingestion rate (g/person/day), $C$ is the average concentration of mercury in food stuffs ( $\mu \mathrm{g} / \mathrm{g}$ wet weight), RfD is the oral reference dose (mg/kg/day) (US EPA 2017), BW is the average body weight of local residents $(60 \mathrm{~kg}$ ) [31], TA is the average exposure time (365 days/year $\times \mathrm{ED})$.

\subsubsection{The Combined Risk of Many Heavy Metals}

The TTHQ of heavy metals for individual foodstuff was treated as the mathematical sum of each individual metal THQ value [34]:

TTHQ individual foodstuff $=$ THQ (toxicant 1$)+$ THQ (toxicant 2$)+\ldots \ldots+$ THQ (toxicant

$\mathrm{n})=\mathrm{THQ}(\mathrm{Hg})+\mathrm{THQ}(\mathrm{Cu})+\mathrm{THQ}(\mathrm{Zn})+\mathrm{THQ}(\mathrm{Fe})+\mathrm{THQ}(\mathrm{Mn})$

HI for a specific receptor/pathway combination (e.g., diet) was calculated using the following pattern [34]:

$$
\text { HI = TTHQ (foodstuff } 1)+ \text { TTHQ (foodstuff } 2)+ \text { TTHQ (foodstuff } 3)+ \text { TTHQ (foodstuff } 4)
$$

When the HI exceeds 1 , there may be concern for potential health risks.

\subsection{Statistical Analysis}

Significant differences in the content of fatty acids and lipid quality indexes in the muscle tissue of fish studied were estimated using a one-way analysis of variance (ANOVA). Similar, differences in the concentration of heavy metals, between species and organs of the same species were calculated using STATISTICA 13.1 program (StatSoft, Kraków, Poland). Differences were found to be significant at $p$ $<0.05$. When the Bartlett's test showed that the variances were heterogeneous, values in particular groups were transformed $(\log x)$. The correlation coefficients between the content of heavy metals in organs of fish and their size (body weight and total length) were calculated using a STATISTICA 13.1 software. The significance level of $p<0.05$ was used. 


\section{Results and Discussion}

\subsection{Differences in the Content of Heavy Metals}

The muscles of fish examined had significantly higher values of mercury than other organs $(p \leq 0.05)$, except for bream, which had no statistically significant differences between the content of mercury in the muscles and liver of this species $(p>0.05)$ (Table 1). Reverse regularity was observed for the content of $\mathrm{Cu}, \mathrm{Zn}, \mathrm{Mn}$ and $\mathrm{Fe}$. The liver of the examined fish contained more $\mathrm{Cu}$ than other organs $(p \leq 0.05)$. The liver of roach and perch had a significantly higher content of $\mathrm{Fe}$, whereas bream liver had more $\mathrm{Zn}(p \leq 0.05)$. There were no significant differences between the content of Fe in the liver and gills of two species (bream and pike) and between the concentration of $\mathrm{Zn}$ in the liver and gills of perch. In other cases, higher contents of marked metals were observed in the gills of the examined fish $(p \leq 0.05)$.

Table 1. Interspecific differences (mean $\pm \mathrm{SD}$ ) in the content of heavy metals in the organs of the same fish species.

\begin{tabular}{|c|c|c|c|c|c|c|c|c|}
\hline & \multicolumn{2}{|c|}{$\begin{array}{c}\text { Bream } \\
\text { Abramis brama L. } \\
(\mathrm{n}=5)\end{array}$} & \multicolumn{2}{|c|}{$\begin{array}{c}\text { Roach } \\
\text { Rutilus rutilus L. } \\
(\mathrm{n}=9)\end{array}$} & \multicolumn{2}{|c|}{$\begin{array}{c}\text { Pike } \\
\text { Esox lucius L. } \\
(\mathrm{n}=6)\end{array}$} & \multicolumn{2}{|c|}{$\begin{array}{c}\text { Perch } \\
\text { Perca fluviatilis L. } \\
(\mathbf{n}=\mathbf{8})\end{array}$} \\
\hline & \multicolumn{8}{|c|}{ Mg/kg Wet Weight } \\
\hline Length (cm) & 48.1 & 4.8 & 30.8 & 7.2 & 61.1 & 8.7 & 28.2 & 6.8 \\
\hline Weight (g) & 1438.0 & 521.7 & 426.2 & 272.9 & 1601.7 & 675.3 & 386.0 & 274.2 \\
\hline Muscles Cu & $0.210^{\mathrm{c}}$ & 0.053 & $0.208^{c}$ & 0.127 & $0.155^{c}$ & 0.029 & $0.137^{c}$ & 0.048 \\
\hline Fills $\mathrm{Cu}$ & $0.766^{\mathrm{b}}$ & 0.062 & $1.366^{\mathrm{b}}$ & 1.181 & $0.486^{b}$ & 0.099 & $0.849^{b}$ & 0.535 \\
\hline Liver Cu & $11.92^{\mathrm{a}}$ & 9.313 & $5.749^{\mathrm{a}}$ & 4.718 & $3.475^{\mathrm{a}}$ & 1.710 & $2.085^{\mathrm{a}}$ & 1.211 \\
\hline Muscles Zn & $4.183^{c}$ & 0.915 & $4.522^{c}$ & 1.035 & $10.020^{c}$ & 1.763 & $4.352^{b}$ & 0.520 \\
\hline Gills Zn & $16.81^{b}$ & 0.968 & $78.33^{a}$ & 31.67 & $115.1^{\mathrm{a}}$ & 22.95 & $22.21^{\mathrm{a}}$ & 6.316 \\
\hline Liver Zn & $34.46^{\mathrm{a}}$ & 10.08 & $35.38^{b}$ & 25.38 & $35.41^{b}$ & 8.095 & $23.72^{a}$ & 3.331 \\
\hline Muscles Mn & $0.122^{\mathrm{c}}$ & 0.032 & $0.106^{\mathrm{c}}$ & 0.054 & $0.090^{c}$ & 0.039 & $0.048^{\mathrm{c}}$ & 0.022 \\
\hline Gills Mn & $5.148^{a}$ & 1.751 & $3.874^{\mathrm{a}}$ & 0.638 & $3.402^{\mathrm{a}}$ & 1.150 & $2.394^{\mathrm{a}}$ & 1.666 \\
\hline Liver Mn & $1.230^{b}$ & 0.481 & $0.843^{b}$ & 0.413 & $1.095^{b}$ & 0.092 & $1.149^{b}$ & 0.355 \\
\hline Muscles Fe & $1.309^{b}$ & 0.286 & $1.005^{\mathrm{c}}$ & 0.435 & $0.833^{b}$ & 0.170 & $1.030^{c}$ & 0.360 \\
\hline Gills Fe & $20.91^{\mathrm{a}}$ & 2.571 & $16.89^{b}$ & 8.253 & $23.38^{a}$ & 12.01 & $17.59^{b}$ & 4.211 \\
\hline Liver Fe & $30.65^{a}$ & 18.56 & $44.74^{\mathrm{a}}$ & 6.364 & $21.16^{\mathrm{a}}$ & 6.163 & $26.40^{\mathrm{a}}$ & 7.352 \\
\hline Muscles Hg & $0.065^{\mathrm{a}}$ & 0.021 & $0.140^{a}$ & 0.033 & $0.297^{a}$ & 0.111 & $0.346^{a}$ & 0.271 \\
\hline Gills Hg & $0.006^{b}$ & 0.002 & $0.025^{\mathrm{c}}$ & 0.008 & $0.047^{\mathrm{c}}$ & 0.029 & $0.050^{\mathrm{c}}$ & 0.028 \\
\hline Liver Hg & $0.050^{\mathrm{a}}$ & 0.045 & $0.059^{b}$ & 0.030 & $0.121^{b}$ & 0.015 & $0.147^{b}$ & 0.055 \\
\hline
\end{tabular}

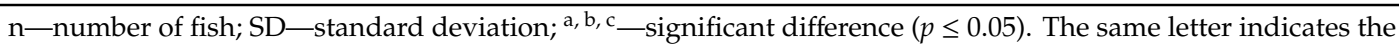
absence of significant differences between organs of the same fish studied.

In most cases, it was not found that the feeding type of fish had a significant effect on the content of such elements as $\mathrm{Cu}, \mathrm{Zn}, \mathrm{Fe}$ and Mn (Figure 2). Predatory fish (perch and pike) which occupy the last link in the trophic chain of the aquatic ecosystem contained more mercury in the muscles and liver than those of the studied fish belonging to the lower trophic levels (bream and roach) $(p \leq 0.05)$. This regularity was not found in gills of the examined fish $(p>0.05)$. 


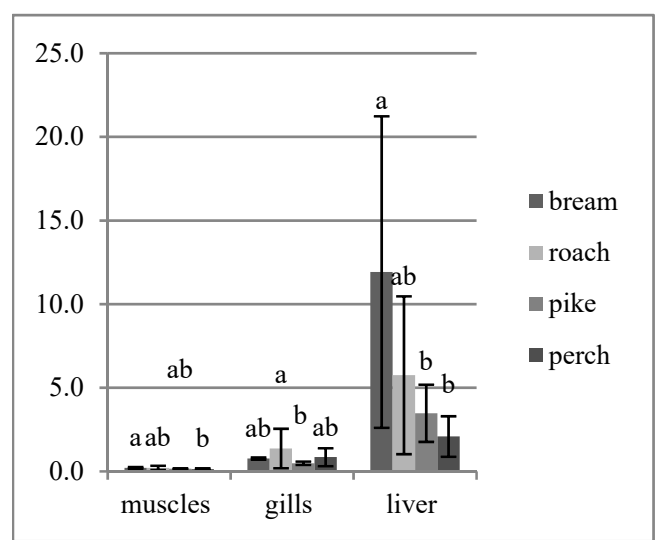

(a)

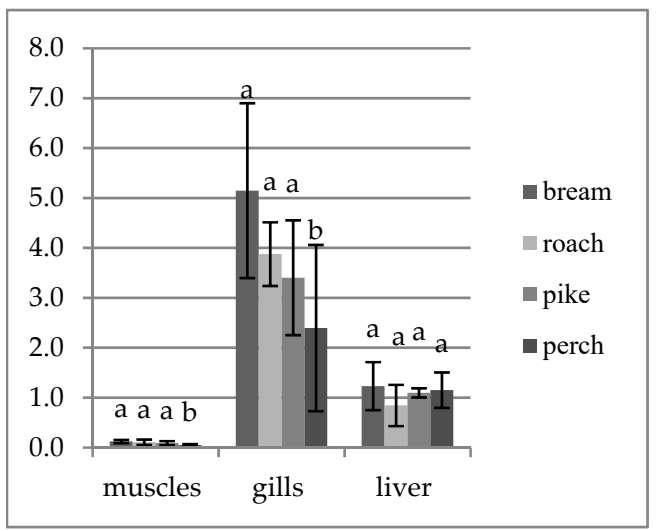

(c)

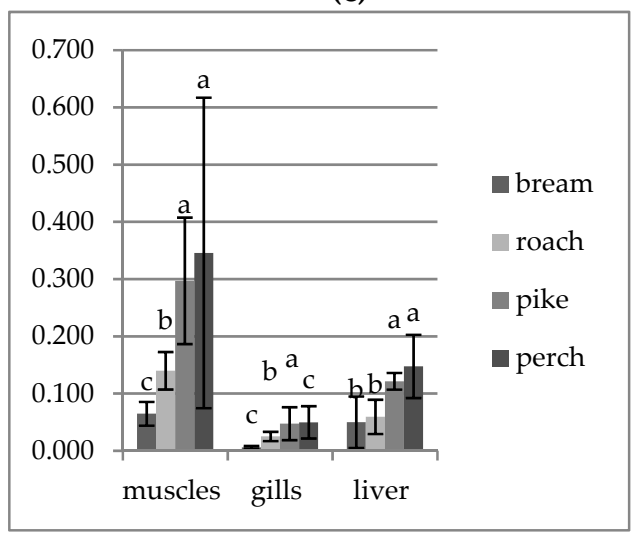

(e)

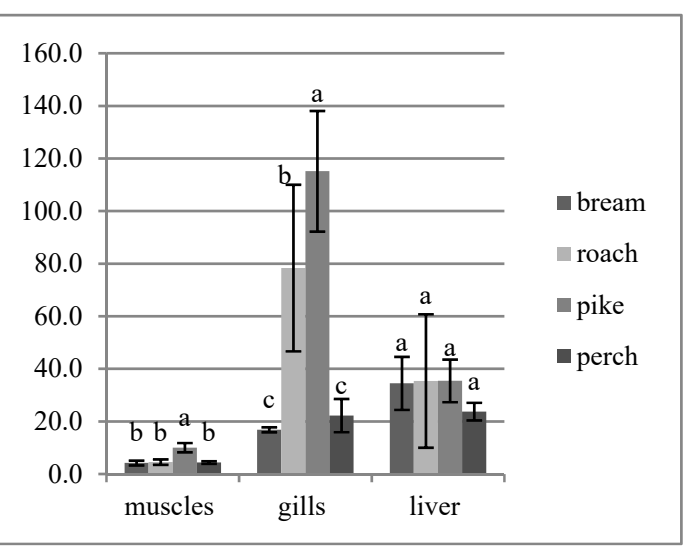

(b)

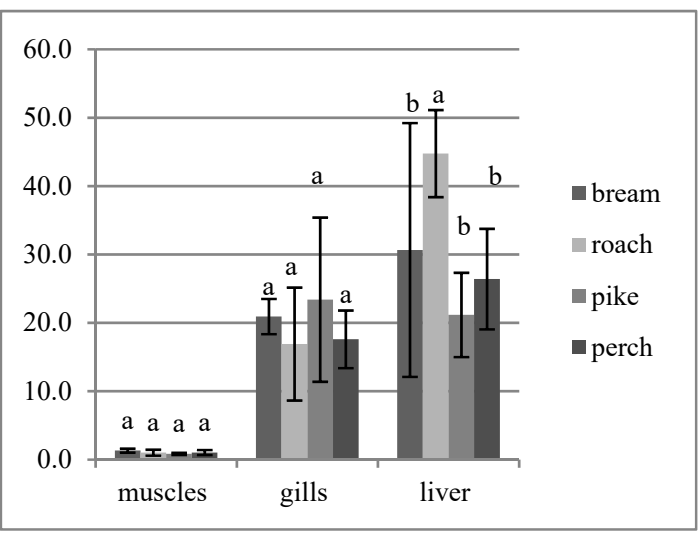

(d)

Figure 2. Differences (mean $\pm \mathrm{SD}$ ) in the content of heavy metals in the same organs of fish (a) $\mathrm{Cu}$, (b) Zn, (c) Mn, (d) Fe and (e) Hg; a, b, c-significant differences between the same organs of the different species $(p \leq 0.05)$. The same letter indicates the absence of significant differences $(p>0.05)$.

Generally, the concentration of 18 elements, including $\mathrm{Hg}$, $\mathrm{Fe}, \mathrm{Cu}, \mathrm{Mn}$ and $\mathrm{Zn}$ significantly differed between species such as sichel (Pelecus cultratus), ruffe (Gymnocephalus cernua) and European perch (Perca fluviatilis), caught at a polluted segment of the Danube River near Belgrade $(p<0.0001)$ [35]. Similarly, Sayegh Petkovšek et al. [36] found that fish (Abramis brama danubii, Alburnus alburnus alburnus, Barbus meridionalis petenyi, Carassius auratius gibelio, Cyprinus carpio, Lepomis gibossus, Leuciscius cephalus cephalus, Perca fluviatilis, Rutilus rutilus and Scardinus erythrophtlalmus erythrophtlalmus) collected in the Šalek lakes (Slovenia) could be used to assess the bioavailability of metals in freshwater biota, although the concentration of metals (e.g., $\mathrm{Hg}$ and $\mathrm{Zn}$ ) varied significantly between fish species. To compare 
the current results with the research of other authors, Table 2 presents the content of heavy metals of selected fish organs from various aquatic ecosystems located in Europe [35-44]. Based on these data, it was found that in most cases, these results did not coincide with the results covered by the study of this work. First of all, the mercury content does not accumulate along the trophic chain, except for $\mathrm{Hg}$ in the muscles of fish caught from the Kirchera River [37]. In addition, the fish muscles (Table 2) did not contain more mercury than the other examined organs presented in the table. The authors also did not find clear relationships between the content of $\mathrm{Cu}, \mathrm{Mn}, \mathrm{Zn}$ and Fe and the length of the trophic chain of a given water reservoir. Some relationships, where the amount of $\mathrm{Zn}, \mathrm{Cu}$ and $\mathrm{Mn}$ was higher in fish organs inhabiting lower levels of the chain, were observed in fish from the West Morava River Basin [38].

Table 2. The content of heavy metals in organs of freshwater fish ( $\mathrm{mg} / \mathrm{kg}$ wet weight).

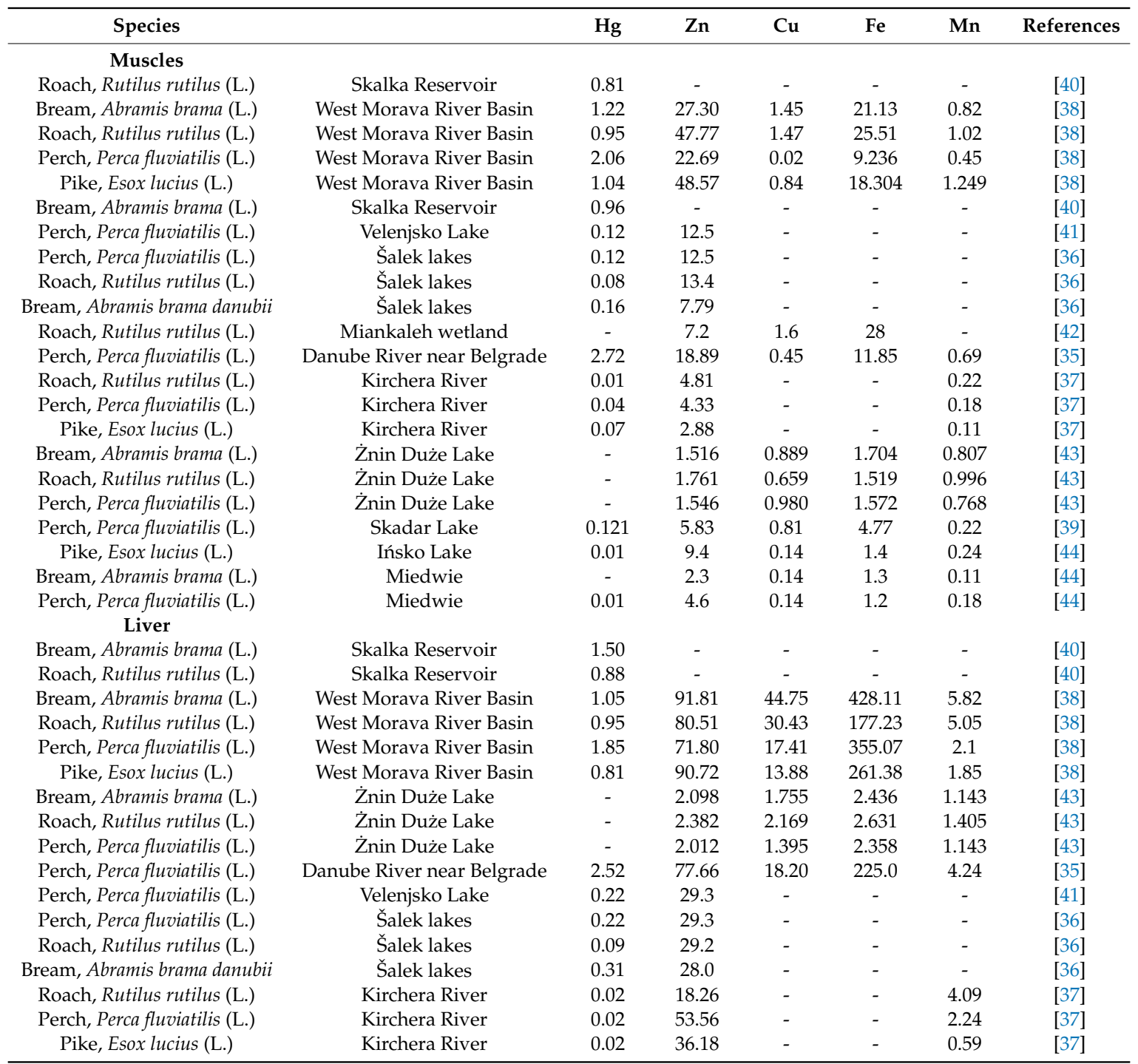


Table 2. Cont.

\begin{tabular}{|c|c|c|c|c|c|c|c|}
\hline Species & & $\mathrm{Hg}$ & $\mathrm{Zn}$ & $\mathrm{Cu}$ & $\mathbf{F e}$ & Mn & References \\
\hline \multicolumn{8}{|l|}{ Gills } \\
\hline Bream, Abramis brama (L.) & West Morava River Basin & 1.31 & 68.46 & 2.36 & 389.61 & 21.45 & [38] \\
\hline Perch, Perca fluviatilis (L.) & West Morava River Basin & 1.8 & 71.2 & 0.99 & 138.52 & 12.29 & [38] \\
\hline Pike, Esox lucius (L.) & West Morava River Basin & 1.27 & 558.11 & 1.56 & 96.69 & 26.83 & [38] \\
\hline Perch, Perca fluviatilis (L.) & Šalek lakes & 0.06 & 24.9 & - & - & - & {$[36]$} \\
\hline Perch, Perca fluviatilis (L.) & Danube River near Belgrade & 1.84 & 64.82 & 0.66 & 189.39 & 10.57 & [35] \\
\hline Bream, Abramis brama (L.) & Żnin Duże Lake & - & 1.937 & 0.650 & 2.436 & 1.745 & [43] \\
\hline Roach, Rutilus rutilus (L.) & Żnin Duże Lake & - & 3.030 & 0.956 & 2.364 & 1.632 & [43] \\
\hline Perch, Perca fluviatilis (L.) & Żnin Duże Lake & - & 1.945 & 0.663 & 2.212 & 1.680 & [43] \\
\hline Perch, Perca fluviatilis (L.) & Velenjsko Lake & 0.06 & 24.9 & - & - & - & [41] \\
\hline
\end{tabular}

References [35,38]—results expressed in $\mathrm{mg} / \mathrm{kg}$ dry weight.

\subsection{Correlation between Metal Pairs and Size}

Figure 3 only shows the significant correlation between metals in fish organs. In other cases, no significant correlations were observed. Significant positive correlation coefficients were found between metal pairs in muscles of perch (Fe-Mn, $\mathrm{Hg}-\mathrm{Cu})$, pike $(\mathrm{Hg}-\mathrm{Zn})$ and roach ( $\mathrm{Cu}-\mathrm{Mn}, \mathrm{Fe}-\mathrm{Zn}, \mathrm{Fe}-\mathrm{Mn})$, gills of perch (Cu-Zn, $\mathrm{Cu}-\mathrm{Mn}, \mathrm{Zn}-\mathrm{Mn})$, pike (Cu-Mn), roach $(\mathrm{Cu}-\mathrm{Zn}$, Fe-Cu, Fe-Mn) and bream (Hg-Cu) and liver of roach $(\mathrm{Fe}-\mathrm{Zn})$.

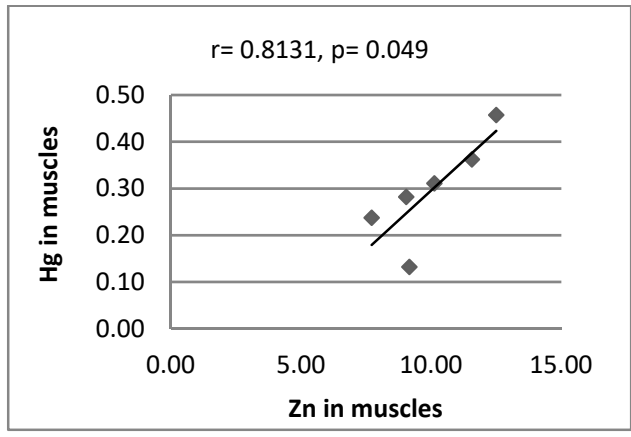

(a)

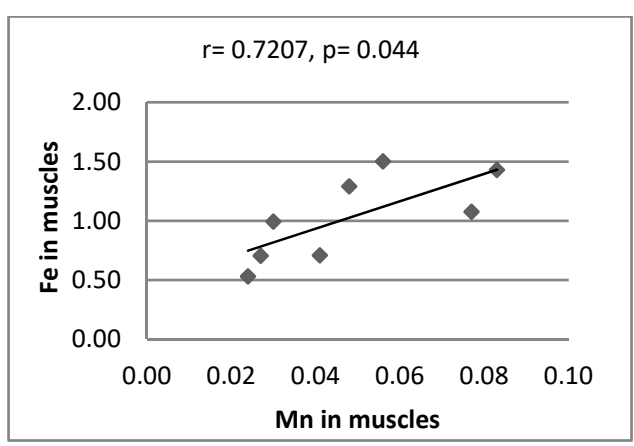

(c)

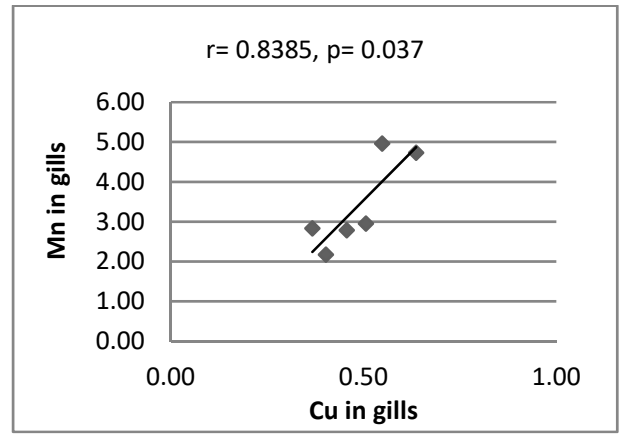

(b)

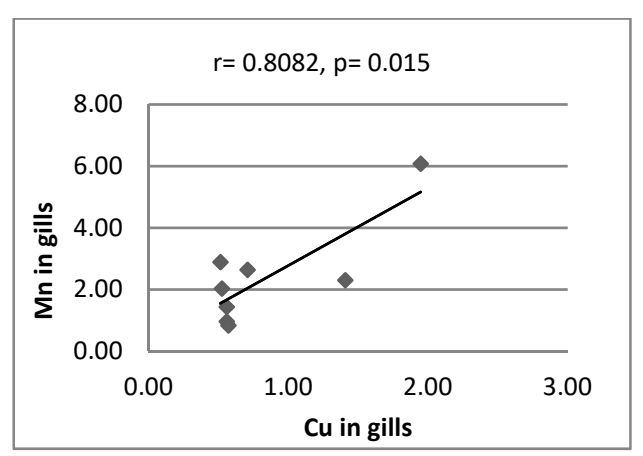

(d)

Figure 3. Cont. 


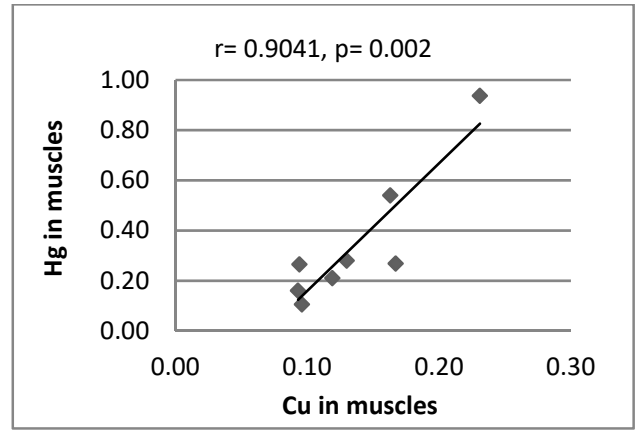

(e)

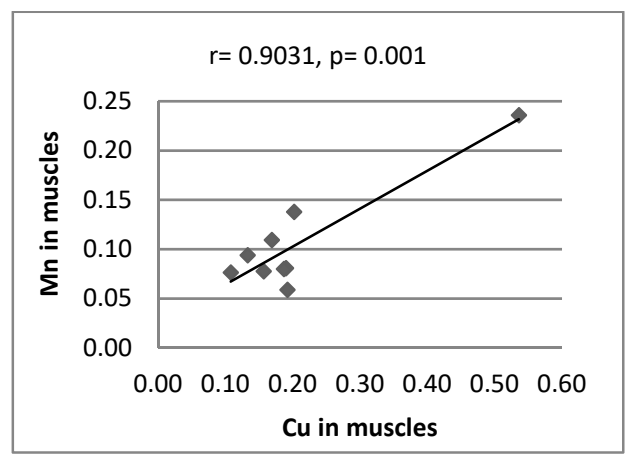

(g)

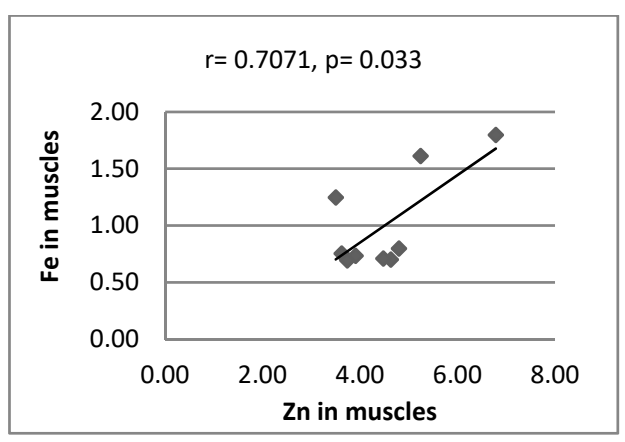

(i)

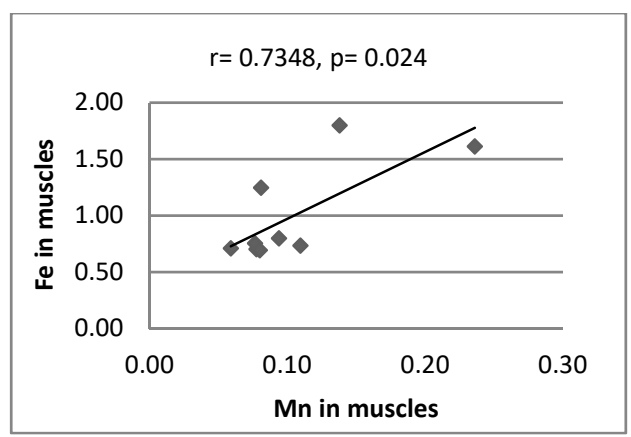

(k)

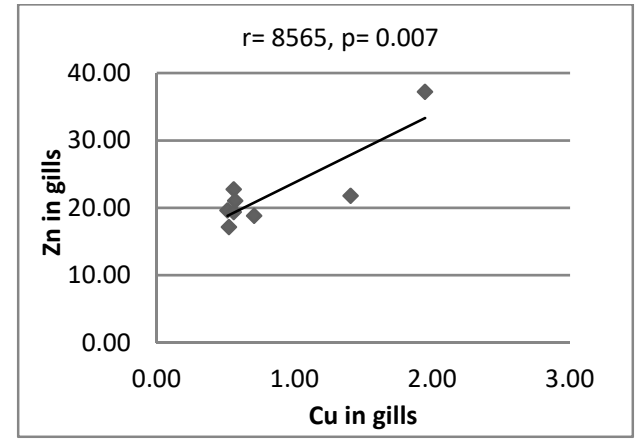

(f)

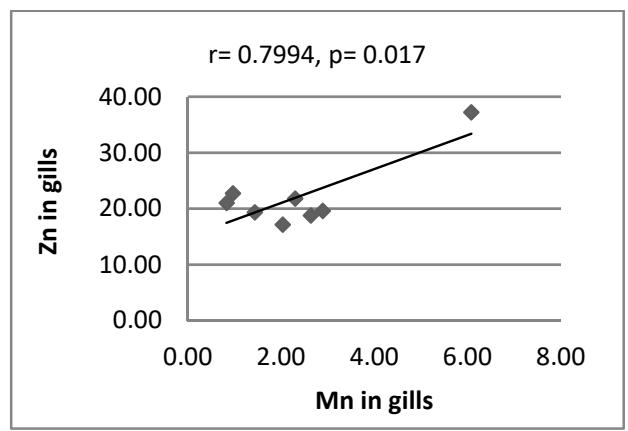

(h)

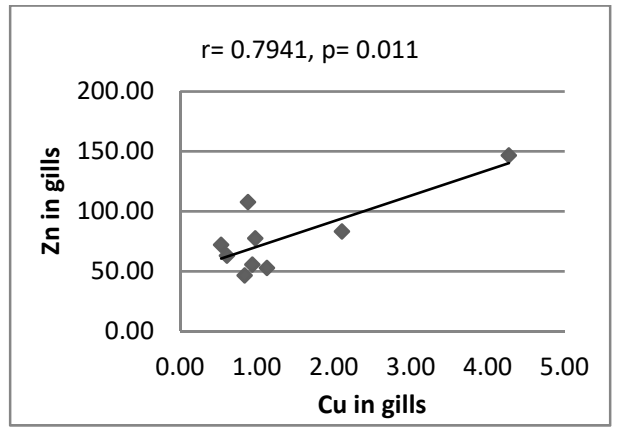

(j)

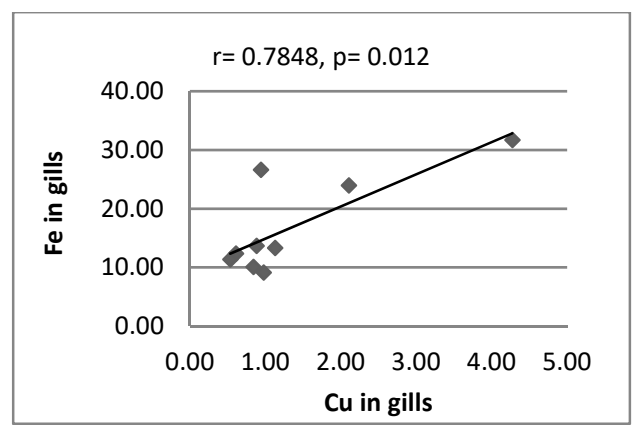

(1)

Figure 3. Cont. 


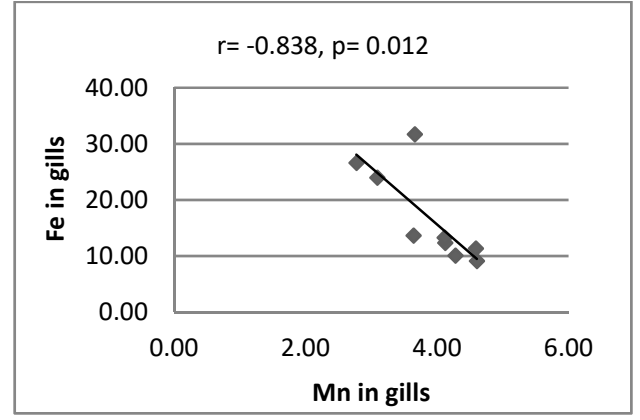

(m)

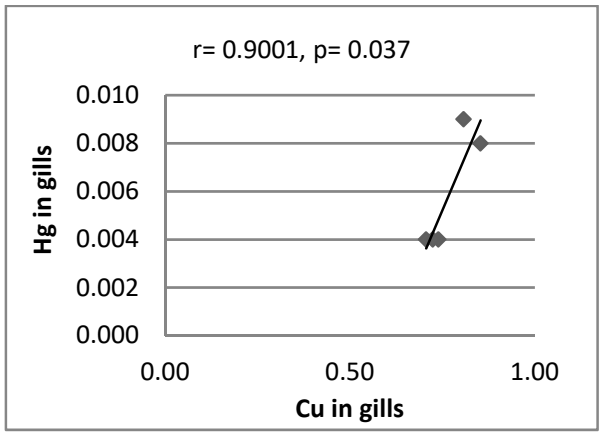

(n)

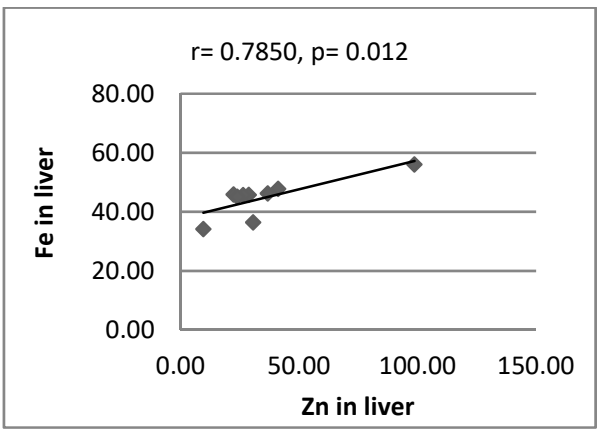

(o)

Figure 3. Correlation between contents of metal (mg/kg wet weight); $\mathrm{r}$-correlation coefficients; p-significant level; (a) pike, (b) pike, (c) perch, (d) perch, (e) perch, (f) perch, (g) roach, (h) perch, (i) roach, $(\mathbf{j})$ roach, $(\mathbf{k})$ roach, $(\mathbf{l})$ roach, $(\mathbf{m})$ roach, $(\mathbf{n})$ bream, $(\mathbf{o})$ roach.

Significant positive correlations were found for Zn-Fe, Zn-Mn, while significant negative correlations were observed for $\mathrm{Zn}-\mathrm{Cu}$ in the muscles of fish (Scardinus knezevici, Alburnus scoranza, Cyprinus carpio, Rutilus prespensis, Anguilla anguilla and Perca fluviatilis) collected from Skadar Lake (Montenegro) [39]. The results obtained by these authors are consistent with the results of the current study, but only for roach muscles. However, the current results are in contradiction with previous studies received by Łuczyńska and Tońska [45].

Figures 4 and 5 only shows the significant correlation between content of metals and size of fish. In other cases, no significant correlations were observed. The content of $\mathrm{Hg}$ in muscles of all fish species was positively correlated with body weight and total length $(p<0.018)$ (Figures 4 and 5). Only the concentration of $\mathrm{Hg}$ in gills and liver of perch increased along with increased body weight $(p=0.000$ and $p=0.004$ ) (Figure 4) and length ( $p=0.008$ and $p=0.002$ ), respectively (Figure 5). Significant positive correlation were also found between the content of $\mathrm{Cu}$ in the muscle tissue of perch and body weight $(p=0.001)$ and length $(p=0.010)$, whereas the content of $\mathrm{Cu}$ in gills of the same species decreased as body weight $(p=0.05)$ and total length $(p=0.003)$ increased. Significant positive correlations between body weight $(p=0.014)$ (Figure 4$)$ and total length $(p=0.020)$ (Figure 5$)$ and the content of Zn were found in muscles of pike. There is a negative correlation between the content of $\mathrm{Zn}, \mathrm{Mn}$ and Fe in muscles of roach and total length ( $p=0.037, p=0.031, p=0.011$, respectively) and between the level of Fe and their body weight $(p=0.043)$ (Figure 4). Negative correlation factors between $\mathrm{Cu}$ content in gills of roach and body weight $(p=0.048)$ and length $(p=0.019)$ were noted. In the case of bream, the content of zinc in gills decreased as body weight increased $(p=0.008)$ (Figure 4). Similarly, Zn in gills and Fe in liver of bream decreased as total length increased ( $p=0.017, p=0.027$, respectively). The obtained results could have been influenced by the variety of conditions of the aquatic environment in which the fish lived, related to the water reaction and the availability of metals. 


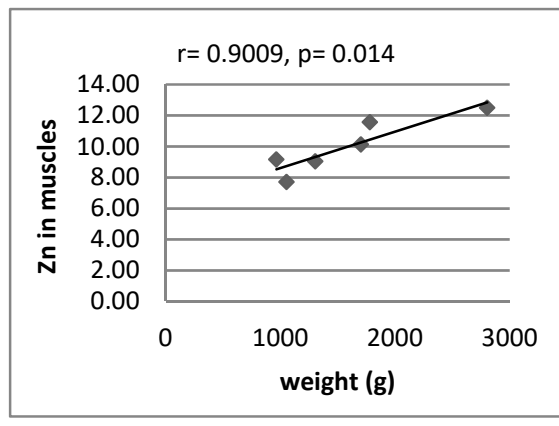

(a)

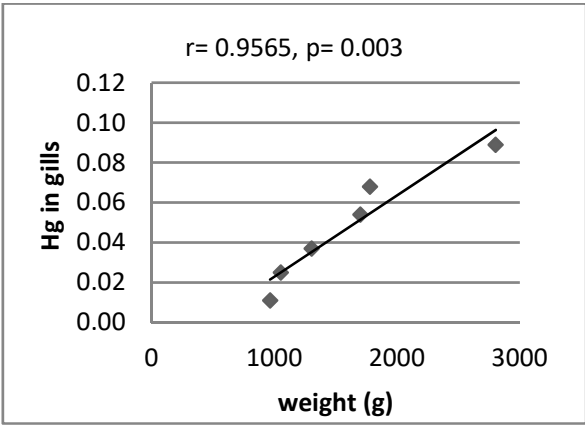

(c)

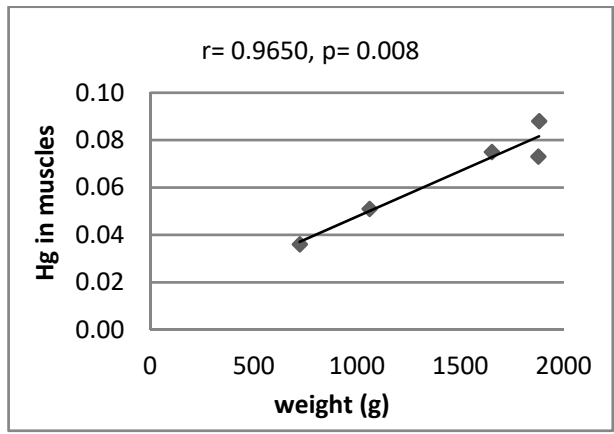

(e)

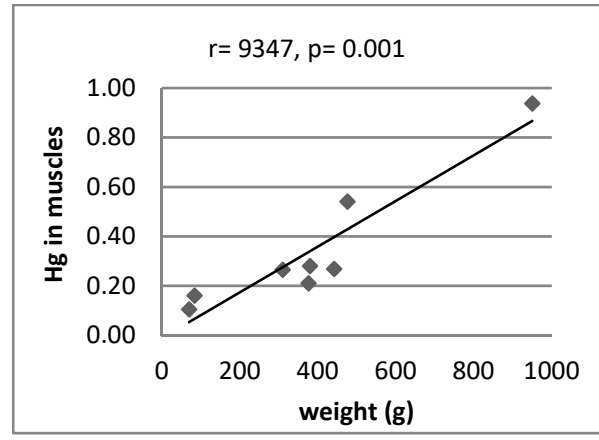

(g)

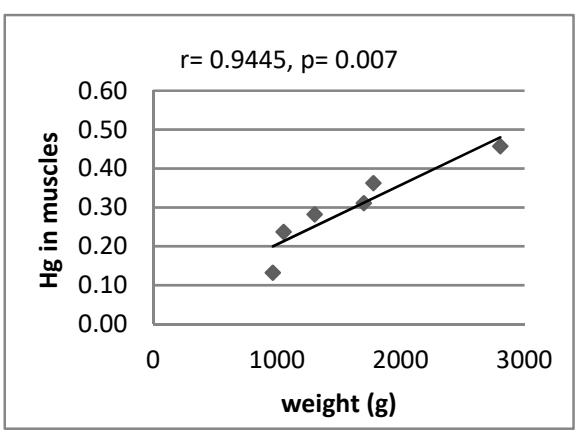

(b)

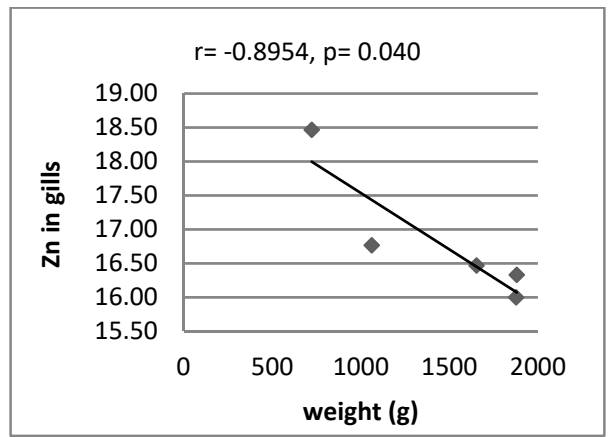

(d)

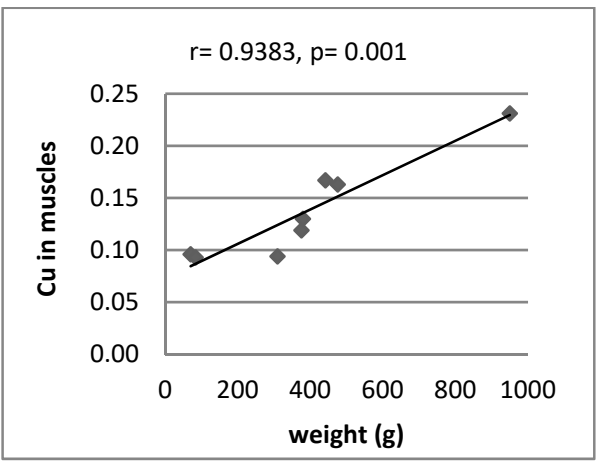

(f)

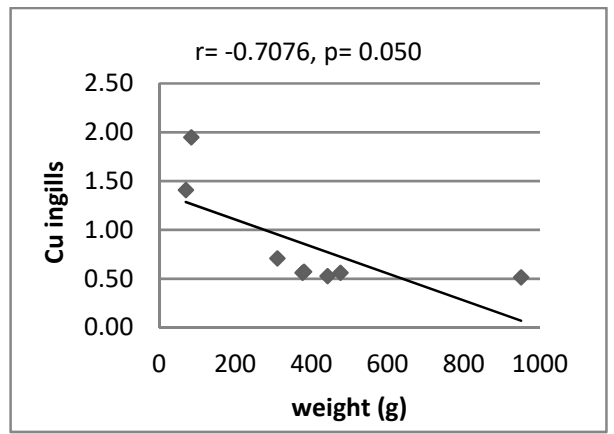

(h)

Figure 4. Cont. 


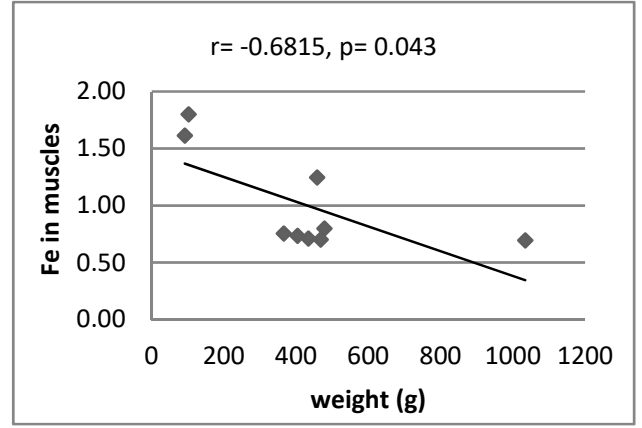

(i)

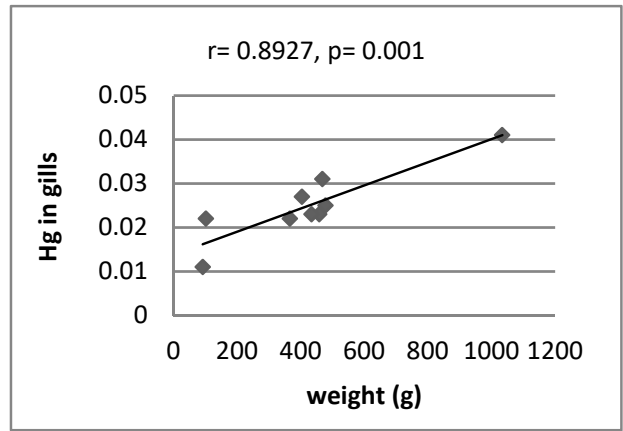

(j)

Figure 4. Correlation between contents of metal ( $\mathrm{mg} / \mathrm{kg}$ wet weight) and weight of fish. $\mathrm{r}$-correlation coefficients; $p$ —significant level; (a) pike, (b) pike, (c) pike, (d) bream, (e) bream, (f) perch, (g) perch, (h) perch, $(\mathbf{i})$ roach, $(\mathbf{j})$ roach.

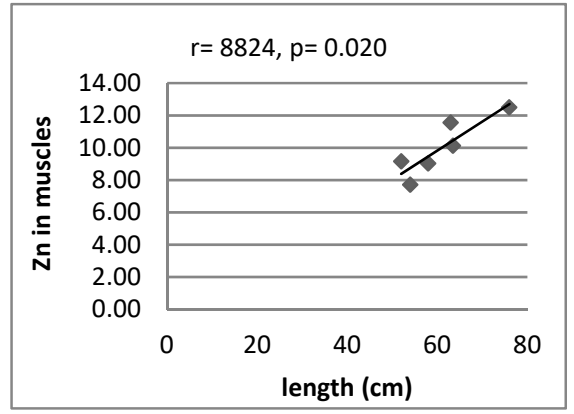

(a)

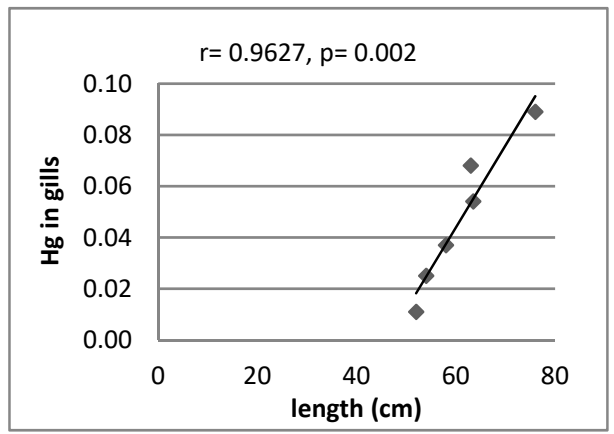

(c)

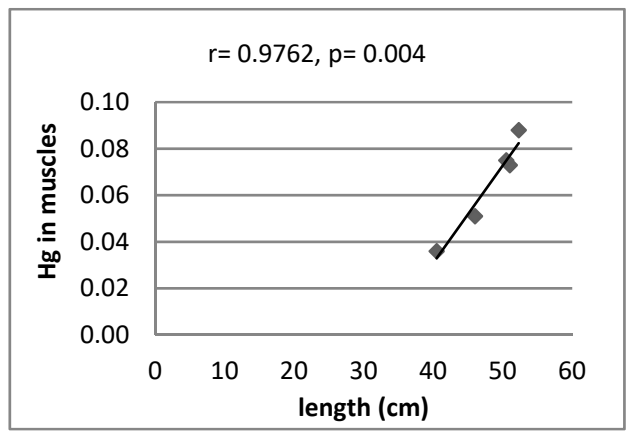

(e)

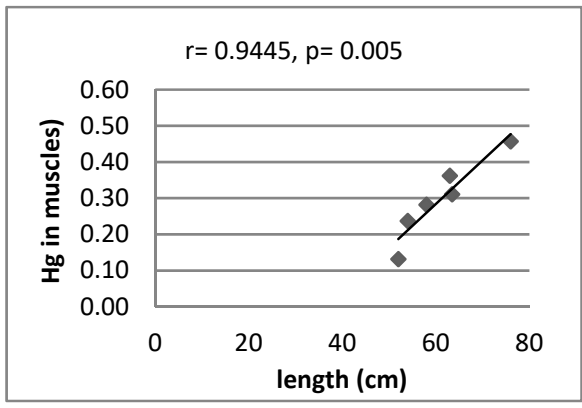

(b)

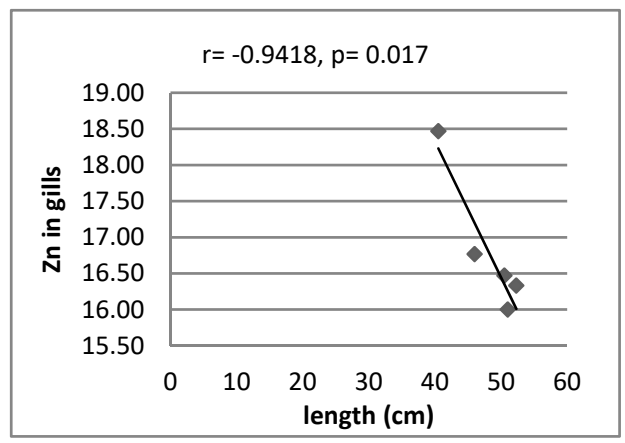

(d)

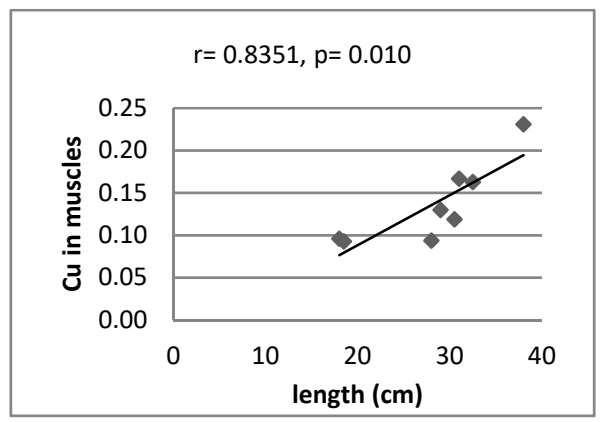

(f)

Figure 5. Cont. 


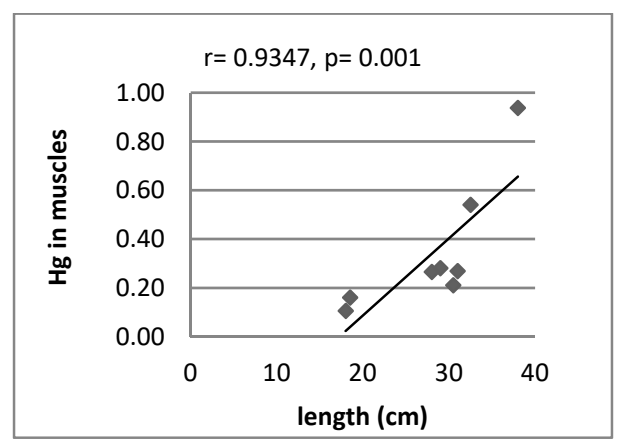

(g)

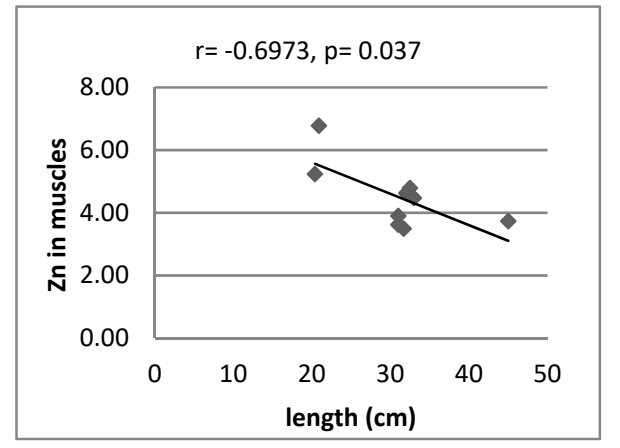

(i)

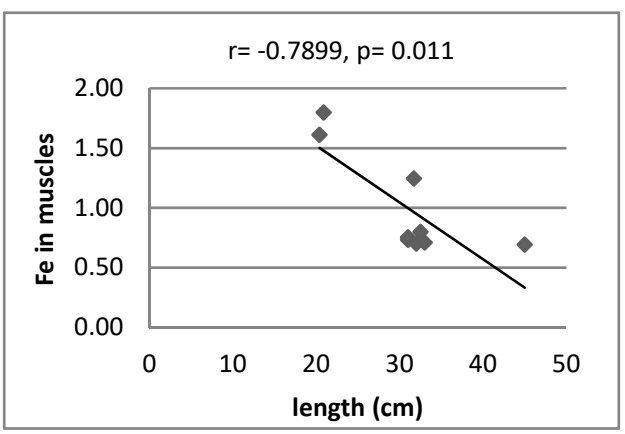

(k)

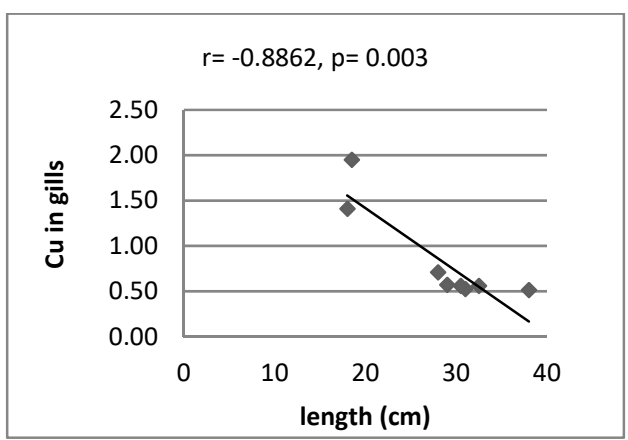

(h)

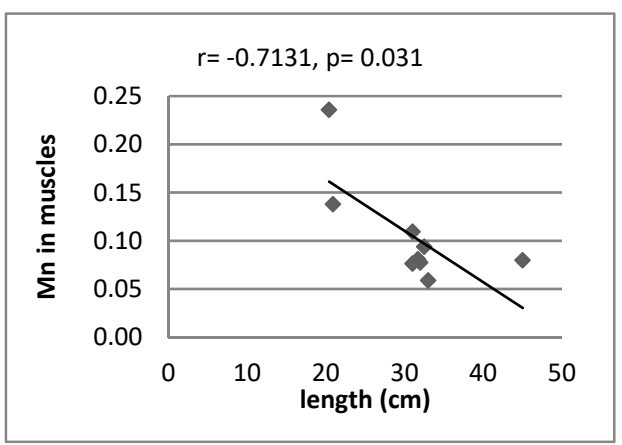

(j)

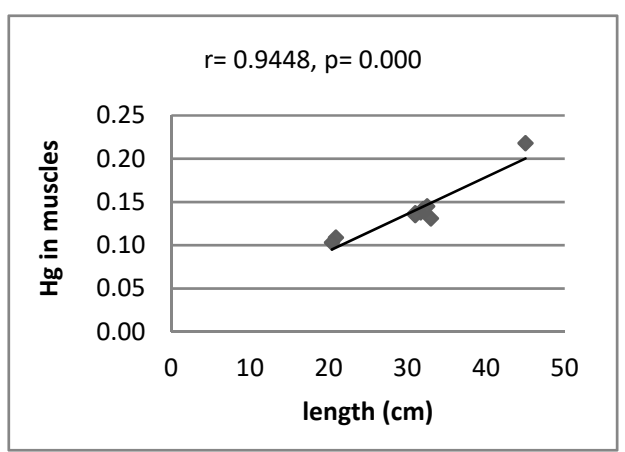

(1)

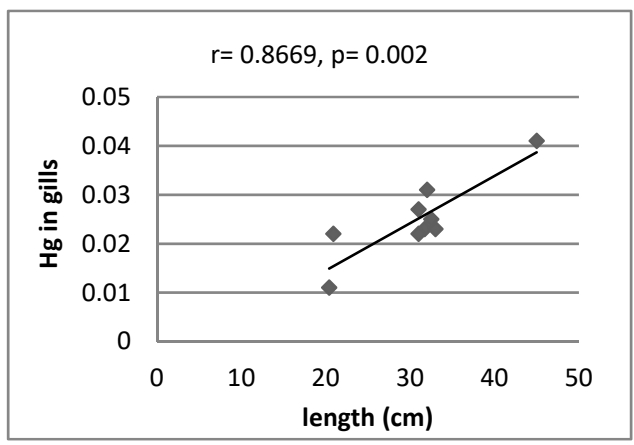

(m)

Figure 5. Correlation between contents of metal ( $\mathrm{mg} / \mathrm{kg}$ wet weight) and length of fish. $\mathrm{r}$-correlation coefficients; $p$-significant level; (a) pike, (b) pike, (c) pike, (d) bream, (e) bream, (f) perch, (g) perch, $(\mathbf{h})$ perch, $(\mathbf{i})$ roach, $(\mathbf{j})$ roach, $(\mathbf{k})$ roach, $(\mathbf{l})$ roach, $(\mathbf{m})$ roach. 
There were no significant correlations between Fe and Hg in muscles of perch (Skandar Lake, Montenegro) and their age or size (length and weight) [39]. However, positive correlation between $\mathrm{Hg}$ in muscles of pike, perch, roach, bream and their size were found in previous studies [24,46,47]. Nozari et al. [48] found a positive correlation between these parameters in muscles of pike from Anzali International Wetland (Iran), while Miller et al. [49] reported a similar correlation in muscles of perch from Swedish and Finnish aquatic environments. This is accordance with the current results (Figures 4 and 5). According to Łuczyńska et al. [47] zinc in the gills of roach was negatively correlated with their weight $(\mathrm{r}=-0.693, p=0.026)$ and length $(\mathrm{r}=-0.668, p=0.035)$. During the study, the correlation was also negative, but not statistically significant (Figures 4 and 5). The same authors found a positive correlation between the $\mathrm{Zn}$ content in gills of perch and their weight $(\mathrm{r}=0.634, p=0.049)$ and no statistically significant correlation between the copper content in the roach and perch organs and their size [47]. This is in contradiction with the results being studied in the current study (Figures 4 and 5).

\subsection{Fatty Acids and Lipid Quality Indexes}

Among the species under study, pike had a significantly higher n-3/n-6 ratio (3.56) and $\Sigma$ n-3 PUFA $(42.61 \%)$ than the other fish species $(p \leq 0.05)$ (Table 3$)$. There were no significant differences between the values of $\Sigma$ SFA (31.73-32.94\%) and $\Sigma$ n-6 PUFA (12.2-14.98\%) in muscles of the examined fish. $\Sigma$ MUFA $(24.12 \%)$ in muscles of bream was significantly higher $(p \leq 0.05)$ than other fish species, with the exception of roach. Among the SFA and MUFA, the predominant fatty acids were palmitic acid C16:0 and oleic acid C18:1, whereas arachidonic C20:4 n-6, eicosapentaenoic EPA n-3 and docosahexaenoic DHA n-3 acids were the most abundant of PUFA.

Atherogenic index (AI), hypocholesterolemic (OFA) and hypercholesterolemic fatty acids (DFA) in muscles of the examined fish did not differ significantly $(p>0.05)$ (Figure 6). The flesh-lipid quality index (FLQ) in the muscles of fish included in this study gave rise to the following sequence: pike $>$ perch $\approx$ roach $>$ bream $(p \leq 0.05)$. No difference was found in terms of thrombogenicity index (TI) (Figure 6) between the species within the following groups (bream, roach and perch) and (roach, pike and perch) $(p>0.05)$. The low values of AI and TI indicates that the tissue of the studied fish is beneficial from a health point of view. Fatty acids with undesirable dietary effect in humans (OFA) were less than DFA, i.e., those desirable. As with heavy metals, there was no clear relationship between the tested fatty acids or selected quality indicators and the fish species or their occurrence in organs and biometric data.

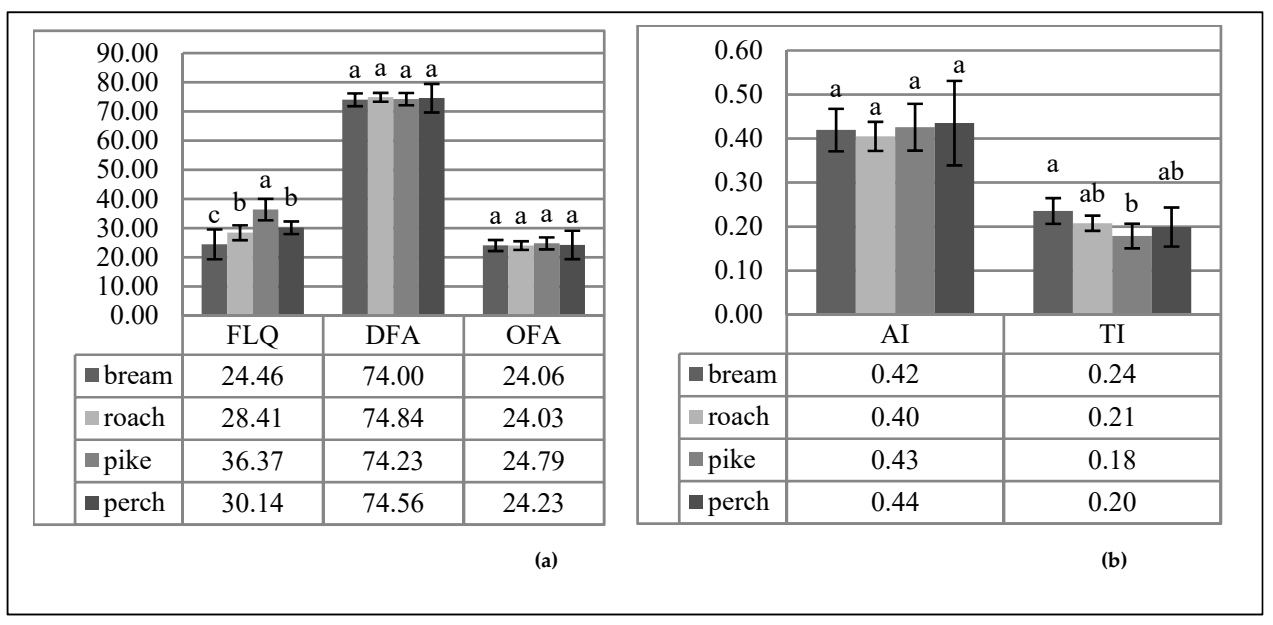

Figure 6. Lipid quality indexes. (a) Flesh-lipid quality (FLQ); hypercholesterolaemic fatty acids (OFA); hypocholesterolaemic fatty acids (DFA); (b) index of atherogenicity (AI); index of thrombogenicity (TI); a, b , c-significant differences between the fish of the different species $(p \leq 0.05)$. The same letter indicates the absence of significant differences $(p>0.05)$. 
Table 3. Fatty acids composition (\% of total fatty acids) in muscles of different fish species.

\begin{tabular}{|c|c|c|c|c|c|c|c|c|}
\hline \multirow[t]{2}{*}{ Fatty Acids } & \multicolumn{2}{|c|}{$\begin{array}{c}\text { Bream } \\
\text { Abramis brama } \mathrm{L} .\end{array}$} & \multicolumn{2}{|c|}{$\begin{array}{c}\text { Roach } \\
\text { Rutilus rutilus L. }\end{array}$} & \multicolumn{2}{|c|}{$\begin{array}{c}\text { Pike } \\
\text { Esox lucius L. }\end{array}$} & \multicolumn{2}{|c|}{$\begin{array}{c}\text { Perch } \\
\text { Perca fluviatilis L. }\end{array}$} \\
\hline & Mean & SD & Mean & SD & Mean & SD & Mean & SD \\
\hline $\mathbf{n}$ & \multicolumn{2}{|c|}{5} & \multicolumn{2}{|c|}{9} & \multicolumn{2}{|c|}{6} & \multicolumn{2}{|c|}{8} \\
\hline C12:0 & $0.43^{a}$ & 0.72 & $0.10^{a}$ & 0.02 & $0.13^{a}$ & 0.01 & $0.11^{a}$ & 0.04 \\
\hline C14:0 & $1.32^{\mathrm{a}}$ & 0.46 & $1.19^{\mathrm{a}}$ & 0.22 & $1.30^{\mathrm{a}}$ & 0.37 & $1.57^{\mathrm{a}}$ & 0.27 \\
\hline C15:0 & $0.73^{\mathrm{a}}$ & 0.33 & $0.45^{b}$ & 0.07 & $0.43^{b}$ & 0.04 & $0.42^{b}$ & 0.08 \\
\hline C16:0 & $22.31^{\mathrm{a}}$ & 1.43 & $22.74^{\mathrm{a}}$ & 1.53 & $23.36^{a}$ & 1.98 & $22.55^{\mathrm{a}}$ & 4.83 \\
\hline C17:0 & $1.03^{\mathrm{a}}$ & 0.68 & $0.59^{b}$ & 0.13 & $0.48^{\mathrm{b}}$ & 0.06 & $0.62^{b}$ & 0.06 \\
\hline C18:0 & $6.94^{\mathrm{a}}$ & 1.26 & $6.55^{\mathrm{a}}$ & 0.78 & $6.57^{\mathrm{a}}$ & 0.38 & $6.81^{\mathrm{a}}$ & 1.51 \\
\hline C20:0 & $0.18^{\mathrm{a}}$ & 0.03 & $0.11^{b}$ & 0.03 & $0.08^{b}$ & 0.02 & $0.16^{\mathrm{a}}$ & 0.05 \\
\hline C14:1 & $0.05^{\mathrm{a}}$ & 0.05 & $0.04^{\mathrm{ab}}$ & 0.03 & $0.00^{b}$ & 0.00 & $0.03^{\mathrm{ab}}$ & 0.04 \\
\hline C16:1 & $6.03^{a}$ & 3.43 & $4.81^{\mathrm{ab}}$ & 1.73 & $1.94^{\mathrm{c}}$ & 0.36 & $3.52^{b c}$ & 0.90 \\
\hline C17:1 & $0.75^{\mathrm{a}}$ & 0.20 & $0.46^{\mathrm{b}}$ & 0.19 & $0.37^{\mathrm{b}}$ & 0.09 & $0.49^{\mathrm{b}}$ & 0.06 \\
\hline C18:1 & $16.32^{\mathrm{a}}$ & 6.68 & $12.93^{\mathrm{ab}}$ & 3.47 & $9.85^{b}$ & 1.40 & $12.11^{\mathrm{ab}}$ & 2.78 \\
\hline C20:1 (n-7) & $0.20^{\mathrm{a}}$ & 0.05 & $0.22^{\mathrm{a}}$ & 0.05 & $0.12^{b}$ & 0.01 & $0.11^{\mathrm{b}}$ & 0.03 \\
\hline C20:1 (n-9) & $0.46^{\mathrm{a}}$ & 0.24 & $0.52^{\mathrm{a}}$ & 0.18 & $0.39^{\mathrm{a}}$ & 0.19 & $0.32^{\mathrm{a}}$ & 0.12 \\
\hline C20:1 (n-11) & $0.31^{\mathrm{a}}$ & 0.10 & $0.43^{\mathrm{a}}$ & 0.19 & $0.05^{b}$ & 0.08 & $0.00^{b}$ & 0.00 \\
\hline C18:2(n-6) & $3.36^{\mathrm{a}}$ & 0.54 & $2.28^{\mathrm{a}}$ & 0.76 & $2.95^{\mathrm{a}}$ & 0.24 & $3.13^{a}$ & 1.83 \\
\hline $\mathrm{C} 18: 3 \gamma-\operatorname{lin}(\mathrm{n}-6)$ & $0.32^{\mathrm{a}}$ & 0.08 & $0.20^{b}$ & 0.06 & $0.21^{b}$ & 0.02 & $0.30^{\mathrm{a}}$ & 0.06 \\
\hline C20:2(n-6) & $0.70^{\mathrm{a}}$ & 0.19 & $0.67^{\mathrm{a}}$ & 0.22 & $0.56^{\mathrm{a}}$ & 0.09 & $0.24^{\mathrm{b}}$ & 0.10 \\
\hline C20:3(n-6) & $0.45^{\mathrm{a}}$ & 0.08 & $0.38^{\mathrm{a}}$ & 0.10 & $0.14^{\mathrm{b}}$ & 0.06 & $0.21^{b}$ & 0.12 \\
\hline$C 20: 4(n-6)$ & $7.63^{\mathrm{ab}}$ & 2.03 & $8.51^{\mathrm{a}}$ & 1.93 & $6.44^{\mathrm{b}}$ & 1.85 & $8.71^{\mathrm{a}}$ & 0.80 \\
\hline$C 22: 5(n-6)$ & $1.10^{\mathrm{b}}$ & 0.50 & $2.94^{\mathrm{a}}$ & 1.43 & $2.03^{\mathrm{ab}}$ & 0.49 & $1.57^{\mathrm{b}}$ & 0.47 \\
\hline C18:3(n-3) & $1.40^{\mathrm{a}}$ & 0.49 & $1.24^{\mathrm{a}}$ & 0.67 & $1.68^{\mathrm{a}}$ & 0.29 & $2.03^{\mathrm{a}}$ & 1.76 \\
\hline C18:4 (n-3) & $0.19^{b}$ & 0.12 & $0.31^{b}$ & 0.21 & $0.75^{\mathrm{a}}$ & 0.11 & $0.68^{a}$ & 0.25 \\
\hline C20:3(n-3) & $0.48^{\mathrm{a}}$ & 0.29 & $0.42^{a}$ & 0.16 & $0.22^{b}$ & 0.06 & $0.23^{b}$ & 0.09 \\
\hline C20:4(n-3) & $0.54^{\mathrm{a}}$ & 0.10 & $0.81^{\mathrm{a}}$ & 0.44 & $0.59^{\mathrm{a}}$ & 0.07 & $0.74^{\mathrm{a}}$ & 0.29 \\
\hline C20:5(n-3) EPA & $8.43^{a}$ & 0.49 & $7.12^{a}$ & 2.30 & $7.36^{\mathrm{a}}$ & 1.25 & $9.26^{\mathrm{a}}$ & 4.55 \\
\hline $\mathrm{C} 22: 5(\mathrm{n}-3)$ & $2.32^{b}$ & 0.47 & $2.72^{a b}$ & 0.29 & $3.00^{\mathrm{ab}}$ & 0.32 & $3.20^{\mathrm{a}}$ & 1.07 \\
\hline C22:6(n-3) DHA & $16.03^{b}$ & 4.63 & $21.30^{b}$ & 3.41 & $29.02^{a}$ & 3.61 & $20.88^{b}$ & 5.70 \\
\hline$\Sigma$ SFA & $32.94^{\mathrm{a}}$ & 3.28 & $31.73^{\mathrm{a}}$ & 2.07 & $32.34^{a}$ & 2.47 & $32.24^{\mathrm{a}}$ & 6.33 \\
\hline$\Sigma$ MUFA & $24.12^{\mathrm{a}}$ & 10.30 & $19.40^{\mathrm{ab}}$ & 5.45 & $12.73^{\mathrm{b}}$ & 1.76 & $16.58^{b}$ & 3.60 \\
\hline$\Sigma \mathrm{n}-6$ PUFA & $13.55^{\mathrm{a}}$ & 2.34 & $14.98^{\mathrm{a}}$ & 2.63 & $12.32^{a}$ & 2.32 & $14.15^{\mathrm{a}}$ & 2.16 \\
\hline$\Sigma$ n-3 PUFA & $29.39^{c}$ & 5.90 & $33.91^{b}$ & 3.25 & $42.61^{\mathrm{a}}$ & 3.92 & $37.02^{b}$ & 1.82 \\
\hline$\Sigma$ PUFA & $42.94^{\mathrm{c}}$ & 8.19 & $48.89^{b}$ & 4.24 & $54.93^{\text {a }}$ & 3.69 & $51.17^{\mathrm{ab}}$ & 3.22 \\
\hline$n-3 / n-6$ & $2.16^{\mathrm{b}}$ & 0.12 & $2.32^{b}$ & 0.42 & $3.56^{\mathrm{a}}$ & 0.67 & $2.66^{\mathrm{b}}$ & 0.35 \\
\hline
\end{tabular}

SD—standard deviation; ${ }^{a}, b, c \_$significant differences $(p \leq 0.05)$. The same letter (in rows) indicates the absence of significant differences ( $p>0.05$ ), $\Sigma$ SFA (saturated fatty acid), $\Sigma$ MUFA (monounsaturated fatty acid), $\Sigma \mathrm{n}-6$ PUFA (polyunsaturated fatty acid), $\Sigma$ n-3 PUFA (polyunsaturated fatty acid), EPA-eicosapentaenoic acid (C20:5), DHA-docosahexaenoic acid (C22:6).

Many studies indicate that the fatty acids that dominated the muscles of the fish in the current study are the same groups of fatty acids found in the muscles of the species of fish in other studies [50-55]. Kainz et al. [56] found that n-3 and n-6 PUFA in fish of pre-alpine Lake Lunz (Austria) decreased with increasing trophic position, demonstrating that these essential fatty acids did not biomagnify with increasing trophic level. These observations are not consistent with the results of the current study (Table 3). Previous studies conducted by Łuczyńska et al. [51] also found that n-3 and n-6 PUFA did not differ between predatory and non-predatory fish. Based on the results, it can be stated that the values of these indices were not affected by the level of the trophic chain and, thus, the diet of the fish. Łuczyńska et al. [57], did not find any significant differences either between these indices for fish such as bream and perch, which occupy two different links in the aquatic ecosystem food chain. The results of the current research on AI and TI (Figure 6) are consistent with studies conducted by Linhartová et al. [58] which found that the indicators in all analyzed fish, except for Nile tilapia, were below 0.5, which indicates significant benefit to human health if these fish are included in the human diet. AI and TI for seven freshwater fish species, including perch and bream, from the Czech Republic were close to the values given for the Eskimo diet, which indicates the high nutritional value of these fish and, therefore, not a threat [59]. According to Linhartová et al. [58] the higher values of these coefficients, 
the higher risk of developing cardiovascular diseases, because AI indicates the risk of diseases such as atherosclerosis (deposition of fat in the walls of the arteries) and TI determines the possibility of blood clots. Tilami et al. [59] showed that AI and TI for bream and perch were 0.30 and 0.38 or 0.25 and 0.22 , respectively. Similar values were found in these species of fish subject to this study (Figure 6).

\subsection{Human Health Risk}

Fish consumption in 2013 year (Poland) was $12.2 \mathrm{~kg}$ per capita/year (for an adult with a body weight of $60 \mathrm{~kg}$ ) [60]. Therefore, the estimated daily intake (EDI) of $\mathrm{Cu}, \mathrm{Zn}, \mathrm{Mn}, \mathrm{Fe}$ and $\mathrm{Hg}$ from the $33.42 \mathrm{~g} /$ person/day were: $0.076-0.117,2.330-5.582,0.027-0.068,0.489-0.729$ and $0.036-0.193$, respectively (Table 4). The THQ and HI as individual foodstuff (TTHQ) were below 1 (Table 5), whereas HI for a specific receptor/pathway combination (e.g., diet) exceeded 1 . This may suggest that eating meat from a given species is a non-carcinogenic health risk for consumers.

Table 4. Estimated daily intake EDI ( $\mu \mathrm{g} / \mathrm{kg}$ body weight/day).

\begin{tabular}{cccccc}
\hline & Cu & Zn & Mn & Fe & Hg \\
\hline Abramis brama L. $(\mathrm{n}=5)$ & 0.117 & 2.330 & 0.068 & 0.729 & 0.036 \\
Rutilus rutilus L. $(\mathrm{n}=9)$ & 0.116 & 2.519 & 0.059 & 0.560 & 0.078 \\
Esox lucius L. $(\mathrm{n}=6)$ & 0.086 & 5.582 & 0.050 & 0.489 & 0.165 \\
Perca fluviatilis L. $(\mathrm{n}=8)$ & 0.076 & 2.424 & 0.027 & 0.574 & 0.193 \\
\hline
\end{tabular}

Table 5. The hazard quotient calculated for metals content in the muscle tissue of fish.

\begin{tabular}{|c|c|c|c|c|c|c|c|}
\hline & $\mathrm{Cu}$ & Zn & Mn & $\mathrm{Fe}$ & $\mathrm{Hg}$ & & \\
\hline \multirow[t]{2}{*}{$\begin{array}{c}\text { RfD } \\
\text { (mg/kg/day) }\end{array}$} & $4.00 \times 10^{-2}$ & $3.00 \times 10^{-1}$ & $1.4 \times 10^{-1}$ & $7.00 \times 10^{-1}$ & $3.00 \times 10^{-4}$ & & \\
\hline & & & THQ & & & TTHQ & HI \\
\hline Abramis brama L. $(\mathrm{n}=5)$ & 0.0029 & 0.0078 & 0.0005 & 0.0010 & 0.1200 & 0.132 & \multirow{4}{*}{1.630} \\
\hline Rutilus rutilus L. $(\mathrm{n}=9)$ & 0.0029 & 0.0084 & 0.0004 & 0.0008 & 0.2596 & 0.272 & \\
\hline Esox lucius L. $(\mathrm{n}=6)$ & 0.0022 & 0.0186 & 0.0004 & 0.0007 & 0.5512 & 0.573 & \\
\hline Perca fluviatilis L. $(\mathrm{n}=8)$ & 0.0019 & 0.0081 & 0.0002 & 0.0008 & 0.6418 & 0.653 & \\
\hline TDHQ & 0.010 & 0.043 & 0.0015 & 0.003 & 1.573 & & \\
\hline
\end{tabular}

n—number of fish; THQ—Target Hazard Quotient; RfD—Oral reference dose (mg/kg/day) [33]; TDHQ—individual toxicant; TTHQ—individual foodstuff; HI—Hazardous Index.

Łuczyńska et al. [57], studied European perch and bream from the Polish market, and found that the THQ values were also below 1 and there was no carcinogenic health risk to the consumer by consuming fish. According to these authors the daily intake (EDI) of mercury was: $0.009 \mu \mathrm{g} / \mathrm{body}$ weight (bream) and 0.076 (perch). EDI of mercury from the portion of fish examined was higher (Table 4). THQ and $\mathrm{HI}$ of $\mathrm{Cu}, \mathrm{Zn}$ and $\mathrm{Hg}$ in European perch and roach from Lake Pluszne were lower than 1, which is important for the local community and other people who use the lake for recreational purposes [42], although the EDI of zinc and copper from the $33.698 \mathrm{~g}$ portions of fish was higher and the EDI of mercury was lower than the examined fish (Table 4). According to Addo-Bediako et al. [61], when THQ $<1$, these adverse health effects are unlikely, whereas THQ $>1$ suggests a high probability of adverse health effects. A THQ value (for Mn and $\mathrm{Zn}$ ) below 1 in the roach muscles from the Miankaleh international wetland was also obtained by the Alipour et al. [42]. There was also no threat from metals, including $\mathrm{Cu}, \mathrm{Fe}, \mathrm{Mn}$ and $\mathrm{Zn}$, in the consumption of fish living in lakes, rivers, streams, and the sea in Sakarya (Turkey) [62]. This is accordance with the results obtained in the current study. On the basis of the 18 elements under study, the authors observed that both bream and zander are among the best fish species to monitor the quality of fish tissue, but fisheries monitoring programs should also include other economically important fish species (e.g., common carp, pike and barbell) and some exotic species, such as Prussian carp [63]. 


\section{Conclusions}

Based on the hazard factor for individual metals THQ $<1$, it was found that the consumption of the studied fish does not constitute a carcinogenic health risk. Similarly, when the mathematical sum of each THQ value for a given species of fish is considered, their consumption does not raise concerns related to adverse health risks. However, when a specific receptor/pathway combination (e.g., diet) was calculated, which posed a threat from the consumption of all fish species simultaneously contaminated with test elements, there could be concerns about potential health risk because HI was below 1. Looking at the low daily intake of fish, it appears that these fish are safe from a nutritional and health point of view. It was also observed that these fish are a rich source of fatty acids and the proportions between fatty acids with desirable dietary effects (DFA) and those with undesirable effects (OFA) were in favor of the former. In addition, AI and TI lipid quality indices in fish muscles were low, which means that fish tissue is beneficial to consumers. There was no clear relationship between the tested heavy metals, fatty acids or selected quality indicators and the fish species or their occurrence in organs and biometric data. Such a relationship could be observed only in relation to mercury, which accumulated in fish occupying individual levels of the trophic chain, with humans at the end. However, its levels did not exceed acceptable standards.

Author Contributions: J.Ł. had the original idea for the study and wrote the manuscript and conducted the statistical analysis; B.P. and J.Ł. collected and analyzed the data; B.P. contributed in the writing of the section "Analytical methods". All authors read and approved the final manuscript.

Funding: The study was financed by the statutory theme number $17.610 .008-300$ and the project was financially supported by the Minister of Science and Higher Education in the range of the program entitled "Regional Initiative of Excellence" for the years 2019-2022, project number 010/RID/2018/19, and the amount of funding was 12.000.000 PLN.

Conflicts of Interest: The authors declare that there is no conflict of interests.

\section{References}

1. Strungaru, S.-A.; Nicoră, M.; Rău, M.A.; Plăvan, G.; Micu, D. Do you like to eat fish? An overview of the benefits of fish consumption and risk of mercury poisoning. Analele Stiintifice ale Universitătii "Alexandru Ioan Cuza" din Iași, s. Biologie animală. 2015, 61, 117-123.

2. Pal, J.; Shukla, B.N.; Maurya, A.K.; Verma, H.O.; Pandey, G.; Amitha. A review on role of fish in human nutrition with special emphasis to essential fatty acid. Int. J. Fish Aqu. Stud. 2018, 6, 427-430.

3. Simopoulos, A.P. Human requirement for n-3 polyunsaturated fatty acids. Poult. Sci. 2000, 79, 961-970. [CrossRef]

4. Steffens, W. Freshwater fish-Wholesome foodstuffs. Bulg. J. Agric. Sci. 2006, 12, 320-328.

5. Mohanty, B.P. Nutritional value of food fish. In Conspectus of Inland Fisheries Management; Das, A.K., Panda, D., Eds.; Barrackpore: West Bengal, India, 2015.

6. Kaur, N.; Chugh, V.; Gupta, A.K. Essential fatty acids as functional components of foods-A review. J. Food Sci. Technol. 2014, 51, 2289-2303. [CrossRef]

7. Candela, C.G.; López, L.M.B.; Kohen, V.L. Importance of a balanced omega 6/omega 3 ratio for the maintenance of health. Nutritional recommendations. Nutr. Hosp. 2011, 26, 323-329. [CrossRef]

8. Johnson, M.; Bradford, C. Omega-3, omega-6 and omega-9 fatty acids: Implications for cardiovascular and other diseases. J. Glycom. Lipidom. 2014, 4, 1-8. [CrossRef]

9. Kris-Etherton, P.M.; Harris, W.S.; Appel, L.J. Fish consumption, fish oil, omega-3 fatty acids, and cardiovascular disease. Circulation 2002, 106, 2747-2757. [CrossRef] [PubMed]

10. Arbex, A.K.; Bizarro, V.R.; Santos, J.C.S.; Araújo, L.M.M.; de Jesus, A.L.C.; Fernandes, M.S.A.; Salles, M.M.; Rocha, D.R.T.W.; Marcadenti, A. The Impact of the Essential Fatty Acids (EFA) in Human Health. OJEMD 2015, 5, 98-104. [CrossRef]

11. Bowen, K.J.; Harris, W.S.; Kris-Etherton, P.M. Omega-3 fatty acids and cardiovascular disease: Are there benefits. Curr. Treat. Options Cardio. Med. 2016, 18, 1-16. [CrossRef]

12. Ristić-Medić, D.; Vučić, V.; Takić, M.; Karadžić, I.; Glibetić, M. Polyunsaturated fatty acids in health and disease. J. Serb. Chem. Soc. 2013, 78, 1269-1289. [CrossRef] 
13. FAO Food and Nutrition Paper. Fats and Fatty Acids in Human Nutrition; Report of an Expert Consultation; FAO: Geneva, Switzerland, 2008.

14. Kris-Etherton, P.M.; Yu, S. Individual fatty acid effects on plasma lipids and lipoproteins: Human studies. Am. J. Clin. Nutr. 1997, 65, 1628-1644. [CrossRef] [PubMed]

15. Thorgilsson, B.; Nunes, M.L.; Gunnlaungsdóttir, H. Review of Evidence for the Beneficial Effect of Fish Consumption; Skýrsla Matís 51-10; Matísohf/Matis-Food Research, Innovation \& Safety: Reykjavík, Iceland, 2010.

16. Jezierska, B.; Witeska, M. Metal Toxicity to Fish; Monographs No 42; Akademia Podlaska: Siedlce, Poland, 2001; 318p.

17. Elbeshti, R.T.A.; Elderwish, N.M.; Abdelali, K.M.K.; Tastan, Y. Effects of Heavy Metals on Fish. MENBA J. Fish. Fac. Sayfa 2018, 4, 36-47.

18. Lieu, P.T.; Heiskala, M.; Peterson, P.A.; Yang, Y. The roles of iron in health and disease. Mol. Asp. Med. 2001, 22, 187. [CrossRef]

19. Vidyavati, S.D.; Sneha, A.; Katti, S.M. Zinc: The Importance in Human Life. IJHBR 2016, 4, 18-20.

20. Chen, P.; Bornhorst, J.; Aschner, M. Manganese metabolism in humans. Front. Biosci. 2018, 23, $1655-1679$. [CrossRef]

21. Desai, V.; Kaler, S.G. Role of copper in human neurological disorders. Am. J. Clin. Nutr. 2008, 88, 855-858. [CrossRef]

22. Skalnaya, M.G.; Skalny, A.V. Essential Trace Elements in Human Health: A Physician's View; Publishing House of Tomsk State University: Tomsk, Russia, 2018; p. 224.

23. Rice, K.M.; Walker, E.M.; Wu, M.; Gillette, C.; Blough, E.R. Environmental mercury and its toxic effects. J. Prev. Med. Public Health 2014, 47, 74-83. [CrossRef]

24. Łuczyńska, J.; Łuczyński, M.J.; Paszczyk, B.; Tońska, E. Concentration of mercury in muscles of predatory and non-predatory fish from lake Pluszne (Poland). J. Vet. Res. 2016, 60, 43-47. [CrossRef]

25. Christie, W.W. The isolation of lipids from tissues. Recommended Procedures. Chloroform-methanol (2:1, v/v) extraction and "Folch" wash. In Lipid Analysis. Isolation, Separation, Identification and Structural Analysis of Lipids; Christie, W.W., Ed.; Pergamon Press Oxford: New York, NY, USA; Toronto, ON, Canada; Sydney, Austrilia; Braunschweig, Germany, 1973; pp. 39-40.

26. Żegarska, Z.; Jaworski, J.; Borejszo, Z. Evaluation of the Peisker modified method for extracting methyl esters from fatty acids. Acta Acad. Agric. Technol. 1991, 24, 25-33. (In Polish)

27. Ulbricht, T.; Southgate, D. Coronary heart disease: Seven dietary factors. Lancet 1991, 338, 985-992. [CrossRef]

28. Garaffo, M.A.; Vassallo-Agius, R.; Nengas, Y.; Lembo, E.; Rando, R.; Maisano, R.; Dugo, G.; Giuffrida, D. Fatty acids profile, atherogenic (IA) and thrombogenic (IT) health lipid indices, of raw roe of blue fin tuna (Thunnus thunnus L.) and their salted product "Bottarga". Food Nutr. Sci. 2011, 2, 736-743. [CrossRef]

29. Abrami, G.; Natiello, F.; Bronzi, P.; McKenzie, D.; Bolis, L.; Agradi, E. A comparison of highly unsaturated fatty acid levels in wild and farmed eels (Anguilla anguilla). Comp. Biochem. Physiol. 1992, 101B, $79-81$. [CrossRef]

30. Senso, L.; Suárez, M.D.; Ruiz-Cara, T.; Garcia-Gallego, M. On the possible effects of harvesting season and chilled storage on the fatty acid profile of the fillet of farmed gilthead sea bream (Sparus aurata). Food Chem. 2007, 101, 298-307. [CrossRef]

31. Polak-Juszczak, L.; Nermer, T. Methylmercury and total mercury in eels, Anguilla anguilla, from Lakes in Northeastern Poland: Health risk assessment. EcoHealth 2016, 13, 582-590. [CrossRef] [PubMed]

32. Ahmed, K.; Baki, M.A.; Kundu, G.K.; Islam, S.; Islam, M. Human health risks from heavy metals in fish of Buriganga river, Bangladesh. SpringerPlus 2016, 5, 1697. [CrossRef] [PubMed]

33. US EPA. Regional Screening Level (RSL) Summary Table; United States Environmental Protection Agency: Washington, DC, USA, 2017.

34. Saha, N.; Zaman, M.R. Evaluation of possible health risks of heavy metals by consumption of foodstuffs available in the central market of Rajshahi City, Bangladesh. Environ. Monit. Assess. 2013, 185, 3867-3878. [CrossRef]

35. Subotić, S.; Višnjić-Jeftić, Ž.; Spasić, S.; Hegediš, A.; Krpo-Ćetković, J.; Lenhardt, M. Concentrations of 18 elements in muscle, liver, gills, and gonads of Sichel (Pelecus cultratus), ruffe (Gymnocephalus cernua), and European perch (Perca fluviatilis) in the Danube River near Belgrade (Serbia). Water Air Soil Pollut. 2015, 226-287. [CrossRef] 
36. Al Sayegh-Petkovšek, S.; Mazej Grudnik, Z.; Pokorny, B. Heavy metals and arsenic concentrations in ten fish species from the Šalek lakes (Slovenia): Assessment of potential human health risk due to fish consumption. Environ. Monit. Assess. 2012, 184, 2647-2662. [CrossRef]

37. Pintaeva, E.T.; Bazarsadueva, S.V.; Radnaeva, L.D.; Petrov, E.A.; Smirnova, O.G. Content and character of metal accumulation in fish of the Kichera River (a Tributary of Lake Baikal). Contemp. Probl. Ecol. 2011, 4, 64-68. [CrossRef]

38. Đikanović, V.; Skorić, S.; Gačić, Z. Concentrations of metals and trace elements in different tissues of nine fish species from the Meduvrsje Reservoir (West Morava River Basin, Serbia). Arch. Biol. Sci. 2016, 68, 811-819. [CrossRef]

39. Rakocevic, J.; Sukovic, D.; Maric, D. Distribution and relationships of eleven trace elements in muscle of six fish species from Skadar Lake (Montenegro). Turk. J. Fish Aquat. Sci. 2018, 18, 647-657. [CrossRef]

40. Maršálek, P.; Svobodová, Z.; Randák, T.; Švehla, J. Mercury and methylmercury contamination of fish from the Skalka reservoir: A case study. Acta Vet. Brno 2005, 74, 427-434. [CrossRef]

41. Mazej, Z.; Al Sayegh-Petkovšek, S.; Pokorny, B. Heavy metal concentrations in food chain of Lake Velenjsko jezero, Slovenia: An artificial lake from mining. Arch. Environ. Contam. Toxicol. 2010, 58, 998-1007. [CrossRef] [PubMed]

42. Alipour, H.; Pourkhabbaz, A.; Hassanpour, M. Estimation of potential health risks for some metallic elements by consumption of fish. Water Qual. Expo. Health 2015, 7, 179-185. [CrossRef]

43. Stanek, M.; Janicki, B.; Kupcewicz, B. Content of selected heavy metals in the organs of fish from Żnin Duże Lake. Folia Biol. (Kraków) 2005, 53, 115-119. [CrossRef]

44. Lidwin-Kaźmierkiewicz, M.; Pokorska, K.; Protasowicki, M.; Rajkowska, M.; Wechterowicz, Z. Content of selected essential and toxic metals in meat of freshwater fish from West Pomerania, Poland. Pol. J. Food Nutr. Sci. 2009, 59, 219-224.

45. Łuczyńska, J.; Tońska, E. The effect of fish size on the content of zinc, iron, copper, and manganese in the muscles of perch (Perca fluviatilis L.) and pike (Esox lucius L.). Arch. Pol. Fish 2006, 14, 5-13.

46. Łuczyńska, J. The influence of weight and length on the mercury content in the muscle tissue of fish from four lakes in the Olsztyn Lake District (Poland). Arch. Pol. Fish 2005, 13, 51-61.

47. Łuczyńska, J.; Paszczyk, B.; Łuczyński, M.J. Fish as a bioindicator of heavy metals pollution in aquatic ecosystem of Pluszne Lake, Poland, and risk assessment for consumer's health. Ecotox. Environ. Safe 2018, 153, 60-67. [CrossRef]

48. Nozari, M.; Esmaili-Sari, A.; Riyahi-Bakhtiyari, A.; Aazami, J. Mercury Concentration in Muscle and Liver of Pike (Esoxlucius) Collected from Anzali International Wetland, Iran. Iran. J. Toxicol. 2011, 5, 516-520.

49. Miller, A.; Bignert, A.; Porvari, P.; Danielsson, S.; Verta, M. Mercury in Perch (Perca fluviatilis) from Swedenand Finland. Water Air Soil Pollut. 2013, 224, 1-12. [CrossRef]

50. Polak-Juszczak, L.; Komar-Szymczak, K. Fatty acid profiles and fat contents of commercially important fish from Vistula Lagoon. Pol. J. Food Nutr. Sci. 2009, 59, 225-229.

51. Łuczyńska, J.; Borejszo, Z.; Łuczyński, M.J. The composition of fatty acids in muscles of six freshwater fish species from the Mazurian Great Lakes (northeastern Poland). Arch. Pol. Fish 2008, 16, 167-178. [CrossRef]

52. Cengiz, E.I.; Ünlü, E.; Bașhan, M. Fatty acid composition of total lipids in muscle tissues of nine freshwater fish from the River Tigris (Turkey). Turk. J. Biol. 2010, 34, 433-438. [CrossRef]

53. Łuczyńska, J.; Paszczyk, B.; Borejszo, Z.; Tarkowski, Ł. Fatty acid profile of muscles of freshwater fish from Olsztyn markets. Pol. J. Food Nutr. Sci. 2012, 62, 51-55. [CrossRef]

54. Ljubojevic, D.; Trbovic, D.; Lujic, J.; Bjelic-Cabrilo, O.; Kostic, D.; Novakov, N.; Cirkovic, M. Fatty acid composition of fishes from Inland waters. Bulg. J. Agric. Sci. 2013, 19, 62-71.

55. Łuczyńska, J.; Paszczyk, B.; Łuczyński, M.J. Fatty acid profiles in marine and freshwater fish from fish markets in northeastern Poland. Arch. Pol. Fish 2014, 22, 181-188. [CrossRef]

56. Kainz, M.J.; Hager, H.H.; Rasconi, S.; Kahilainen, K.K.; Amundsen, P.-A.; Hayden, B. Polyunsaturated fatty acids in fishes increase with total lipids irrespective of feeding sources and trophic position. Ecosphere 2017, 8, 1-13. [CrossRef]

57. Łuczyńska, J.; Paszczyk, B.; Nowosad, J.; Łuczyński, M.J. Mercury, fatty acids content and lipid quality indexes in muscles of freshwater and marine fish on the Polish market, risk assessment of fish consumption. Int. J. Environ. Res. Public Health 2017, 14, 1120. [CrossRef] 
58. Linhartová, Z.; Krejsa, J.; Zajíc, T.; Másílko, J.; Sampels, S.; Mráz, J. Proximate and fatty acid composition of 13 important freshwater fish species in central Europe. Aquacult. Int. 2018, 26, 695-711. [CrossRef]

59. Tilami, S.K.; Sampels, S.; Zajic, T.; Krejsa, J.; Másílko, J.; Mráz, J. Nutritional value of several commercially important river fish species from the Czech Republic. PEER J. 2018, 6, e5729. [CrossRef] [PubMed]

60. Statistical Yearbook of Agriculture. 2016; p. 460. Available online: https://stat.gov.pl/files/gfx/ portalinformacyjny/en/defaultaktualnosci/3328/6/11/1/statistical_yearbook_of_agriculture_2016.pdf (accessed on 15 December 2016). (In Polish)

61. Addo-Bediako, A.; Marr, S.M.; Jooste, A.; Luus-Powell, W.J. Human health risk assessment for silver catfish Schilbe intermedius Rüppell, 1832, from two impoundments in the Olifants River, Limpopo, South Africa. Water SA 2014, 40, 607-614. [CrossRef]

62. Küpeli, T.; Altundađ, H.; Imamođlu, M. Assessment of trace element levels in muscle tissues of fish species collected from a River, Stream, Lake, and Sea in Sakarya, Turkey. Hindawi 2014, 2014, 496107. [CrossRef] [PubMed]

63. Jovičić, K.; Lenhardt, M.; Višnjić-Jeftić, Ž.; Đikanović, V.; Skorić, S.; Smederevac-Lalić, M.; Jaćimović, M.; Gačić, Z.; Jarić, I.; Hegediš, A. Assessment of fish stocks and elemental pollution in the Danube, Sava and Kolubara rivers on the territory of the city of Belgrade, Serbia. Acta Zool. Bulg. 2014, 7, 179-184.

(C) 2019 by the authors. Licensee MDPI, Basel, Switzerland. This article is an open access article distributed under the terms and conditions of the Creative Commons Attribution (CC BY) license (http://creativecommons.org/licenses/by/4.0/). 